\title{
Article \\ Exposure to Particulate PAHs on Potential Genotoxicity and Cancer Risk among School Children Living Near the Petrochemical Industry
}

\author{
Nor Ashikin Sopian ${ }^{1}$, Juliana Jalaludin 1,*, Suhaili Abu Bakar ${ }^{2}$ D, Titi Rahmawati Hamedon ${ }^{3}$ \\ and Mohd Talib Latif ${ }^{4}$ (D) \\ 1 Department of Environmental and Occupational Health, Faculty of Medicine and Health Sciences, \\ Universiti Putra Malaysia, UPM Serdang 43400, Selangor, Malaysia; norashikinsopian@gmail.com \\ 2 Department of Biomedical Sciences, Faculty of Medicine and Health Sciences, Universiti Putra Malaysia, \\ UPM Serdang 43400, Selangor, Malaysia; suhaili_ab@upm.edu.my \\ 3 Department of Community Health, Faculty of Medicine and Health Sciences, Universiti Putra Malaysia, \\ UPM Serdang 43400, Selangor, Malaysia; rahmawati@upm.edu.my \\ 4 Department of Earth Sciences and Environment, Faculty of Science and Technology, \\ Universiti Kebangsaan Malaysia, Bangi 43600, Selangor, Malaysia; talib@ukm.edu.my \\ * Correspondence: juliana@upm.edu.my; Tel.: +603-97692401
}

check for updates

Citation: Sopian, N.A.; Jalaludin, J.; Abu Bakar, S.; Hamedon, T.R.; Latif, M.T. Exposure to Particulate PAHs on Potential Genotoxicity and Cancer Risk among School Children Living Near the Petrochemical Industry. Int. J. Environ. Res. Public Health 2021, 18, 2575. https://doi.org/10.3390/ ijerph18052575

Academic Editor: Paul B. Tchounwou

Received: 1 February 2021

Accepted: 25 February 2021

Published: 4 March 2021

Publisher's Note: MDPI stays neutra with regard to jurisdictional claims in published maps and institutional affiliations.

Copyright: (c) 2021 by the authors. Licensee MDPI, Basel, Switzerland. This article is an open access article distributed under the terms and conditions of the Creative Commons Attribution (CC BY) license (https:// creativecommons.org/licenses/by/ $4.0 /)$

\begin{abstract}
This study aimed to assess the association of exposure to particle-bound $\left(\mathrm{PM}_{2.5}\right)$ polycyclic aromatic hydrocarbons (PAHs) with potential genotoxicity and cancer risk among children living near the petrochemical industry and comparative populations in Malaysia. $\mathrm{PM}_{2.5}$ samples were collected using a low-volume sampler for $24 \mathrm{~h}$ at three primary schools located within $5 \mathrm{~km}$ of the industrial area and three comparative schools more than $20 \mathrm{~km}$ away from any industrial activity. A gas chromatography-mass spectrometer was used to determine the analysis of 16 United States Environmental Protection Agency (USEPA) priority PAHs. A total of 205 children were randomly selected to assess the DNA damage in buccal cells, employing the comet assay. Total PAHs measured in exposed and comparative schools varied, respectively, from 61.60 to $64.64 \mathrm{ng} \mathrm{m}^{-3}$ and from 5.93 to $35.06 \mathrm{ng} \mathrm{m}^{-3}$. The PAH emission in exposed schools was contributed mainly by traffic and industrial emissions, dependent on the source apportionment. The 95th percentiles of the incremental lifetime cancer risk estimated using Monte Carlo simulation revealed that the inhalation risk for the exposed children and comparative populations was $2.22 \times 10^{-6}$ and $2.95 \times 10^{-7}$, respectively. The degree of DNA injury was substantially more severe among the exposed children relative to the comparative community. This study reveals that higher exposure to PAHs increases the risk of genotoxic effects and cancer among children.
\end{abstract}

Keywords: polycyclic aromatic hydrocarbons (PAHs); children; DNA damage; industry

\section{Introduction}

Particle-bound polycyclic aromatic hydrocarbons (PAHs) are highly lipophilic and pervasive harmful organic pollutants. They are present ubiquitously in the environment and eventually enter the human body through three main routes: inhalation, ingestion and dermal absorption [1-3]. They can be absorbed into air particles, with carcinogenic and mutagenic properties [4-7]. The Agency for Toxic Substances and Disease Registry (ATSDR) ranks PAH congeners at 9 of 275 in a priority list of hazardous substances due to the potential severe health threat for humans and the environment [8].

Atmospheric PAHs, primarily derived from anthropogenic activities such as industrial operations, vehicle exhausts, refineries, waste incineration and domestic heating, are emitted by incomplete combustion of organic matters at high temperatures [9]. Numerous international studies in petrochemical industrial areas and oil refineries have tracked particulate contamination and severe particulate PAH emissions [10-14]. Nevertheless, 
the adverse health effects on children living in nearby industrial areas have not been extensively investigated.

Owing to their developmental stage and physical and biological conditions, children are among the most vulnerable populations [15]. They are known to have a low metabolism capacity than adults; therefore, contaminated air inhalation can increase the metabolism burden in their small bodies [16]. Health symptoms encountered early in life increase a child's future risk of disease and lead to permanent consequences [15]. In previous research, PAH exposures among a vulnerable population, such as children, have been highlighted [16-23]. Inhalation of particulate-bound PAHs was found to have a significant impact on the well-being of children and to be correlated with their growth [24], lung function impairment [25], obesity [26], low-grade inflammation [2], respiratory symptoms, tachycardia and cell damage [27].

Exposure to high urban and industrial air contaminant concentrations has been closely correlated with genetic damage in the children [20,28-30]. Research by Sánchez-Guerra et al. found that school children living in industrial areas and heavy traffic suffered significant DNA damage compared to students living in less polluted areas [31]. Investigations of the chronic impact of exposure to PAHs helped understand the contribution of environmental exposure as a risk factor for cancer, especially in moderate or low air pollution, with biomarker application [32-34]. In addition, increasing proximity to the industrial zone and the busiest road exposed children to higher PAH contamination levels, increase the risk of childhood cancer and respiratory implications [35-39].

This present study aims to quantify the level of particulate $\mathrm{PAH}$ exposure in the indoor and outdoor environments of schools located in the vicinity of the petrochemical industrial area. The exposure sources of PAHs were identified based on the source diagnostic and principal component analysis (PCA). The incremental lifetime cancer risk (ILCR) for children due to PAH inhalation was assessed using Monte Carlo simulation. Moreover, this study investigated the association of exposure to particulate PAHs with potential genotoxicity among primary school children, as indicated by the DNA damage level in their buccal epithelial cells.

\section{Methods}

\subsection{Study Location}

The $24 \mathrm{~h} \mathrm{PM}_{2.5}$ (fine particle with a diameter generally less than $2.5 \mu \mathrm{m}$ ) sampling for five consecutive school days was carried out at three primary schools located within $5 \mathrm{~km}$ of the petrochemical industrial area, which were referred to as schools S1, S2 and S3. Meanwhile, schools C1, C2 and C3 were three comparative schools situated more than $20 \mathrm{~km}$ away from the industrial area and away from any industrial activity. Both the exposed and the comparative regions were situated in Terengganu, Malaysia (Figure 1). A comprehensive description of the sampling sites can be found in Table S1 (Supplementary Materials). The $\mathrm{PM}_{2.5}$ samples were collected between January to May 2017.

\subsection{Study Population}

The comparative cross-sectional analysis included 234 children aged between 9 and 11 years who met the inclusion and exclusion requirements of the respondent selection. These criteria were determined to evaluate the confounding factor because there was a significant association between the increase in chromosomal damage in a respondent and chronic diseases [40]. Children with a family history of cancer who received radiotherapy or chemotherapy in the past 12 months or X-rays in the past 3 months were excluded from this research. Any radiation exposure might have induced cytogenetic alteration and influence the validity of the outcome of this study [41]. Before the sample collection was conducted, written informed consent was sought from the children' parents or guardians. 


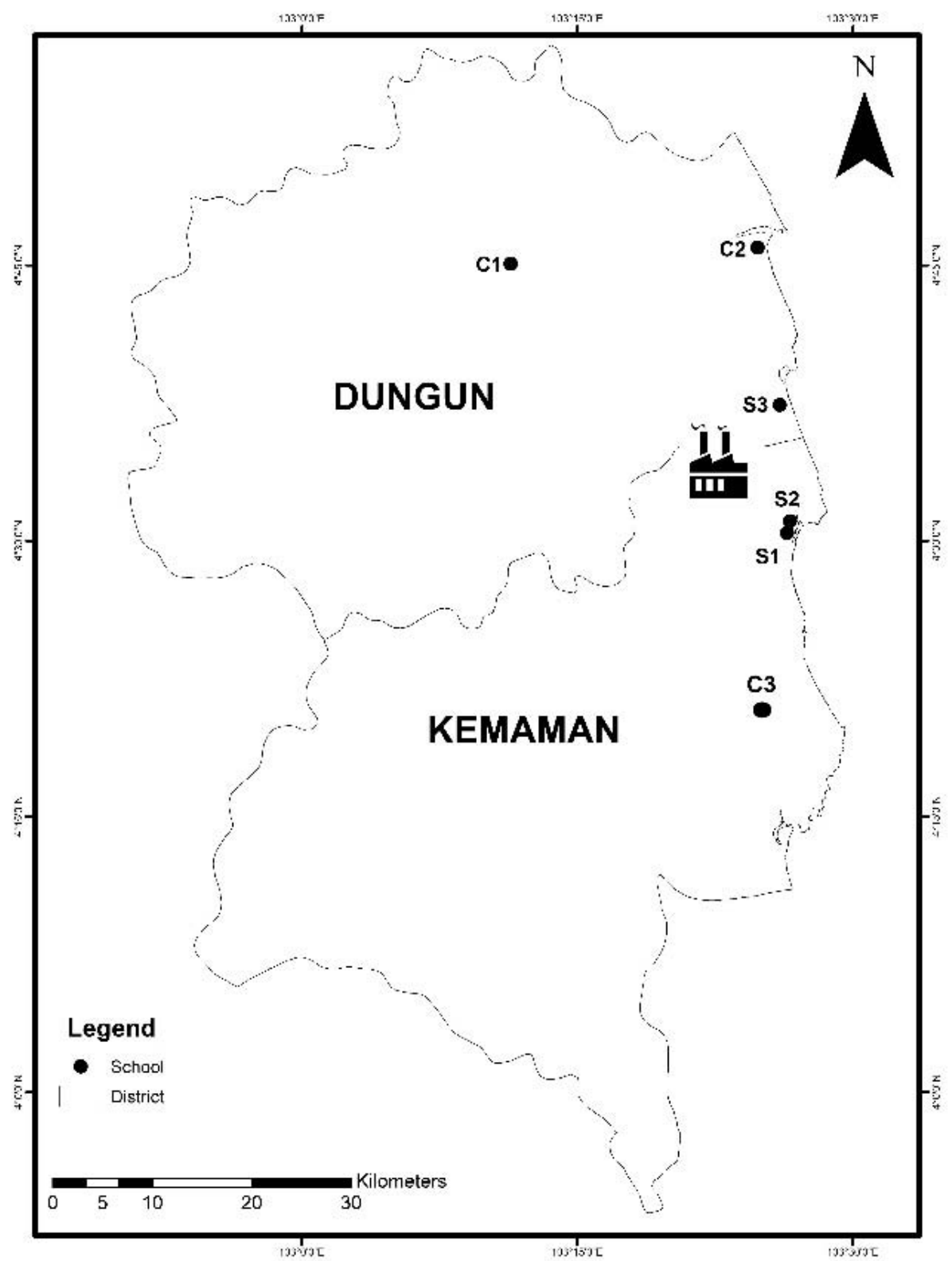

Figure 1. Map of peninsular Malaysia and the study area (Terengganu State). The six schools are located in the districts of Dungun and Kemaman, Terengganu.

\subsection{Measurements of Particulate Matter}

A total of 60 indoor and outdoor $\mathrm{PM}_{2.5}$ samples were collected using a low-volume air sampler equipped with cyclone (Airmetrics Mini Vol, Springfield, OH, USA) with a flow rate of $5 \mathrm{~L} \mathrm{~min}^{-1}$ through weighted quartz microfiber filters ( $47 \mathrm{~mm}$ diameter). The air sampler was positioned approximately $1 \mathrm{~m}$ above the floor and was placed in the school garden and the preferred classroom in a safe area.

\subsection{PAH Analysis}

With a few modifications, the extraction of particulate PAHs by Sulong et al. and Khan et al. was adopted [5,42]. In a glass bottle containing a mix of $10 \mathrm{~mL}$ of dichloromethane (DCM) and n-hexane ( $5 \mathrm{~mL}: 5 \mathrm{~mL})$, filter paper was cut into small pieces. For a total of $30 \mathrm{~min}$, the sample was sonicated in a bath sonicator, with a 2 min run and $1 \mathrm{~min}$ rest. A filtration unit containing an annealed glass fibre filter was used to filter any residual insoluble particles, and the collected solution was purified. Under a gentle blow of nitrogen gas, the extract was concentrated to approximately $0.2 \mathrm{~mL}$ of the extract. Next, to 
reconstitute the extract residue, $0.7 \mathrm{~mL}$ of n-hexane was added gently and spiked with $0.1 \mathrm{~mL}$ of $4.0 \mathrm{ppm}$ standard surrogate perylene before transferring it into a cartridge for solid-phase extraction (SPE).

To clean up and pre-concentrate samples, a silica SPE cartridge (Agela Cleanert CNSPE $1000 \mathrm{mg}^{6} \mathrm{~mL}^{-1}$ ) was used. The SPE cartridge was conditioned with $10 \mathrm{~mL}$ of $\mathrm{n}$-hexane to activate the packing material of the chromatographic sorbent and to allow a proper phase interface with the sample. The final procedure of the SPE operation was followed by PAH elution by a mixture of dichloromethane and n-hexane $(3.5 \mathrm{~mL}: 6.5 \mathrm{~mL})$. Under a gentle stream of nitrogen gas, the eluent was blown down until scorched. Before transferring to a $2 \mathrm{~mL}$ autosampler vial containing a vial insert, it was diluted with $0.1 \mathrm{~mL}$ of $\mathrm{n}$-hexane.

The gas chromatography-mass spectrometry (GCMS) instrument (Agilent Technologies) was calibrated with standard mixtures of PAHs such as naphthalene (NAP), acenaphthene (ACP), acenaphthylene (ACY), anthracene (ANT), fluorene (FLU), phenanthrene (PHE), anthracene (ANT), fluoranthene (FLA), pyrene (PYR), benzo(a)anthracene (BaA), chrysene (CYR), benzo(b)fluoranthene $(\mathrm{BbF})$, benzo(k)fluoranthene $(\mathrm{BkF})$, benzo(a)pyrene $(\mathrm{BaP})$, indeno(1,2,3-cd)pyrene (IcP), dibenzo(a,h)anthracene (DbA) and benzo(ghi)perylene $(\mathrm{BgP})$. The GC column temperature was programmed as follows: initial $40^{\circ} \mathrm{C}$, followed by a temperature increase to $150{ }^{\circ} \mathrm{C}\left(8^{\circ} \mathrm{C}\right.$ per min), and an increment of $4{ }^{\circ} \mathrm{C}$ per min until $310^{\circ} \mathrm{C}$ for a $6 \mathrm{~min}$ hold. The PAH concentration was determined through an internal calibration standard containing a known concentration mixture of $16 \mathrm{PAH}$ congeners. The final concentration PAHs in the $\mathrm{PM}_{2.5}$ was calculated using the following equation, in which the total air volume was $7.2 \mathrm{~m}^{3}$ :

$$
\mathrm{C}\left(\mathrm{ng} \mathrm{m}^{-3}\right)=\mathrm{C} \text { determined }\left(\mathrm{ng} \mathrm{ml}^{-1}\right) \times \text { dilution factor/air volume }\left(\mathrm{m}^{3}\right)
$$

\subsection{Health Risk Assessment}

Risk assessment is an essential method for assessing the adverse effects of PAH exposure on human health, defining the target organ and identifying the particular effects of chemicals to find an appropriate risk minimisation solution [43]. The carcinogenicity potency PAHs can be determined based on the benzo(a)pyrene equivalent concentration (BaPeq), also known as toxicity equivalent concentration (TEQ). Obtaining the TEQ for the PAH compounds requires the involvement of reference toxicity equivalent factors (TEFs) proposed by Nisbet and Lagoy [44], relative to the carcinogenic potency of BaP. The TEQ was determined based on a constant TEF value multiplied with the individual PAHs' concentration, as indicated by the following equation:

$$
\begin{gathered}
\mathrm{TEQ}=0.001(\mathrm{NAP}+\mathrm{ACP}+\mathrm{ACY}+\mathrm{FLU}+\mathrm{PHE}+\mathrm{PYR})+0.01 \\
(\mathrm{ANT}+\mathrm{BgP}+\mathrm{CYR})+0.1(\mathrm{BaA}+\mathrm{BbF}+\mathrm{BkF}+\mathrm{IcP})+\mathrm{BaP}+\mathrm{DbA}
\end{gathered}
$$

Afterwards, the incremental lifetime cancer risk (ILCR) model was used to estimate the carcinogenic risk due to respiratory exposure to PAHs [45-47]. The following equation was employed to calculate the unitless ILCR of PAH exposure in children:

$$
\mathrm{ILCR}=\frac{\mathrm{C} \times \sqrt[3]{\frac{\mathrm{BW}}{70}} \times \mathrm{IR} \times \mathrm{ED} \times \mathrm{EF}}{\mathrm{BW} \times \mathrm{AT}} \times \mathrm{CSF}
$$

where $\mathrm{C}$ indicates the carcinogenic PAHs based on BaPeq $\left(\mathrm{ng} \mathrm{m}^{-3}\right)$ and IR is the air inhalation rate for children $\left(12 \mathrm{~m}^{3} \mathrm{day}^{-1}\right)$ [48]. EF stands for exposure frequency or total schooling day in the year 2017 (250 day year ${ }^{-1}$ ), and ED denotes the exposure duration or length of time of contaminant contact for children (6 years) [48]. BW is the measured body weight of children during the sampling, and AT is the averaging time of carcinogenic PAHs exposure (70 years $\times 365$ days) [48]. CSF refers to inhalation carcinogenic slope for $\mathrm{BaP}$, which is $3.85 \mathrm{mg} \mathrm{kg}^{-1}$ day $^{-1}$ [49].

The ILCR model prediction could either overestimate or underestimate the actual carcinogenic risk. Consequently, the outcome of cancer risk was not applied to the entire 
population of interest. Integrating variability and uncertainty into the risk model is a more precise approach to determine the probabilistic carcinogenic health risk. Therefore, Monte Carlo simulation with 10,000 iterations was employed in this study to appraise the probabilistic ILCR range of children exposed to PAHs for the exposed and comparative schools. The simulation also integrated the uncertainty and variability of the measured PAH concentrations and the specific determinant of children's exposure [47,50,51]. Afterwards, sensitivity analysis was conducted to identify input parameters that significantly influence the estimated risk. Both analyses were implemented using Crystal Ball software (version 11.1.2.4; Oracle Corp., Austin, TX, USA). Table 1 portrays the variable distribution types used in the Monte Carlo simulation for both exposed and comparative schools.

Table 1. Types of variable distribution used in the Monte Carlo simulation.

\begin{tabular}{|c|c|c|c|c|}
\hline Variable & Unit & Distribution Mode & Exposed School & $\begin{array}{c}\text { Comparative } \\
\text { School }\end{array}$ \\
\hline $\begin{array}{c}\text { Toxicity } \\
\text { equivalent } \\
\text { concentration } \\
\text { (TEQ) }\end{array}$ & $n g \mathrm{~m}^{-3}$ & $\begin{array}{c}\text { Logistic \& } \\
\text { Log-normal }\end{array}$ & 17.35 & $2.21,2.51$ \\
\hline $\begin{array}{l}\text { Inhalation rate } \\
\text { (IR) }\end{array}$ & $\mathrm{m}^{3} \mathrm{day}^{-1}$ & Constant & 12 & 12 \\
\hline $\begin{array}{c}\text { Exposure } \\
\text { frequency (EF) }\end{array}$ & day year ${ }^{-1}$ & Constant & 250 & 250 \\
\hline $\begin{array}{c}\text { Exposure } \\
\text { duration (ED) }\end{array}$ & year & Constant & 6 & 6 \\
\hline $\begin{array}{l}\text { Averaging } \\
\text { time }\end{array}$ & days & Constant & 25,500 & 25,500 \\
\hline $\begin{array}{l}\text { Body weight } \\
\text { (BW) }\end{array}$ & $\mathrm{kg}$ & Negative binomial & 0.206 & 0.307 \\
\hline $\begin{array}{l}\text { Cancer slope } \\
\text { factor (CSF) }\end{array}$ & $\mathrm{mg} \mathrm{kg}_{\text {day }^{-1}}^{-1}$ & Constant & 3.85 & 3.85 \\
\hline
\end{tabular}

\subsection{Collection of Exfoliated Buccal Mucosa and MN Assay}

Buccal mucosa cells were obtained by gently scraping the inner sides of both cheeks with a sterile cytology brush. The brush was then dipped into a microcentrifuge tube containing $0.1 \mathrm{M}$ phosphate buffer solution $(\mathrm{pH} 7.5)$ and stored in a freezer at $-20^{\circ} \mathrm{C}$.

\subsection{Comet Assay}

The standard procedure of the Comet Assay Kit (Trevigen, Gaithersburg, MD, USA) was followed to conduct this assay. The cell suspension was washed with sterile phosphatebuffered saline (PBS) solution and centrifuged for $1 \mathrm{~min}$ at $2500 \mathrm{rpm}$ to obtain the precipitate cells. The cells were mixed with $75 \mu \mathrm{L}$ of molten low melting agarose (LMA) (Trevigen, Gaithersburg, MD, USA) and immediately embedded in the comet slide. Next, at $4{ }^{\circ} \mathrm{C}$, the fixed cells underwent a lysing procedure in a pre-chilled lysis solution for $60 \mathrm{~min}$, followed by immersion at room temperature for $60 \mathrm{~min}$ in a freshly prepared alkaline solution. At a constant voltage of $20 \mathrm{~V}$, the slide was immersed for $20 \mathrm{~min}$ in an electrophoresis buffer. It was gently rinsed with $70 \%$ ethanol and deionised water after electrophoresis. The comet images were visualised with a $50 \mu \mathrm{L}$ SyBr Green diluted solution staining effect. A fluorescence microscope randomly captured 100 comet images under $20 \times$ magnification (Motic, Hong Kong, China). Using OpenComet software, which has greater precision and can minimise human bias, the DNA damage was measured as a tail moment [52].

\subsection{Statistical Analysis}

The Statistical Package for Social Science (SPSS) version 22.0 analysed all the data. The normality test determined the subsequent statistical analysis, either parametric or 
non-parametric tests. Bivariate analysis was applied for the mean comparison and the association of the parameters tested in this study. Multiple linear regression was performed to assess the factors contributing to DNA damage among the children.

Using XLSTAT 2020.5.1 software to classify and check the various sources of PAH pollutants in the sampling areas, principal components analysis (PCA) with varimax rotation was carried out [53]. The missing data were substituted by half of the value of the method detection limit (MDL) [18] prior to running PCA. Before proceeding with compatibility data testing, the entire dataset was converted to a dimensionless form. As far as ensuring the compatibility of PCA data was concerned, the Kaiser-Meyer-Olkin (KMO) test and Bartlett's test of sphericity were performed [45]. A KMO value greater than 0.5 indicated that the PAH dataset was in the best condition to be applied in the PCA software.

Additionally, a significant chi-square of Bartlett's test also indicated that the dataset was appropriate to be used. Using the varimax method with Kaiser standardisation, the major elements with eigenvalues greater than one were extracted and rotated. The PCA factor loadings were interpreted depending on the correlation value, which was assumed to be a heavy loading value above 0.75 . Moderate loading varied between 0.50 and 0.75 , and weak loading ranged from 0.30 to 0.50 [54].

\subsection{Quality Control}

To ensure the equilibrium of mass concentration, blank filters were conditioned in a desiccator for $24 \mathrm{~h}$. All the glassware was first washed with running tap water and rinsed with distilled water, followed by hexane, methanol and acetone, to analyse PAHs. To volatilise and eliminate organic contaminants, the glassware and filter paper were baked in a furnace for $4 \mathrm{~h}$ at $400{ }^{\circ} \mathrm{C}[5,42]$.

All samples were spiked with $0.1 \mathrm{~mL}$ of 4 ppm internal standards (chrysene-D12 and perylene-D12) during sample preparation to test for potential organic contamination. For the internal standards, the recovery efficiency ranged from $76 \%$ to $95 \%$. With minimal indirect light exposure to avoid photodegradation, all sample extraction procedures were carried out under a fume hood. Blank filters for the actual samples were extracted and analysed using the same approach to ensure no major background interference. To create calibration curves, five points $\left(0.1\right.$ to $\left.1.0 \mathrm{mg} \mathrm{L}^{-1}\right)$ of the certified reference standard of the EPA 610 Polynuclear Aromatic Hydrocarbons Mixture (Supelco, Bellefonte, PA, USA) were analysed. The limits of detection (LOD) was determined on the basis of independent measurements of the blank sample and its standard deviation. The correlation coefficient and LOD of 16 USEPA priority PAHs are presented in Table S2, Supplementary Material.

Furthermore, the quality control for the comet assay included observation of the zigzag method to prevent overlapping views. The sample of buccal epithelial cells was properly shielded from direct sunlight. Moreover, sample preparation and examination were performed under dim light. During the scoring stage, a potential error in determining DNA damage may occur. To manually mitigate false-positive occurrences, OpenComet software used in the comet assay allows the user to discard the irregular comet shape. Interestingly, a statistical outlier analysis of each comet image was also applied to this software. The inconsistent image has been identified as an outlier and can minimise the number of false positives [52].

\section{Results and Discussion}

\subsection{Distributions of PAH Species at the Exposed and Comparative Schools}

Figure 2 portrays the distributions of particulate PAHs in the exposed and comparative schools, sampled $24 \mathrm{~h}$ during school days. The highest concentration of total PAHs was recorded in exposed school S2, with a mean value of $67.72 \pm 49.84 \mathrm{ng} \mathrm{m}^{-3}$, closely followed by school S1 $\left(64.64 \pm 44.85 \mathrm{ng} \mathrm{m}^{-3}\right)$ and school S3 (61.60 $\pm 39.74 \mathrm{ng} \mathrm{m}^{-3}$ ) (Table S3, Supplementary Materials). On the other hand, the comparative schools located more than $20 \mathrm{~km}$ away from the petrochemical industrial areas reported low PAH concentrations, especially schools C2 (5.93 $\pm 0.59 \mathrm{ng} \mathrm{m}^{-3}$ and C3 $\left(6.36 \pm 1.19 \mathrm{ng} \mathrm{m}^{-3}\right)$. School C1 demon- 
strated a contrary finding, with a concentration six times higher $\left(35.06 \pm 9.71 \mathrm{ng} \mathrm{m}^{-3}\right)$ than the other two schools $\left(5.93 \pm 0.59\right.$ and $\left.6.36 \pm 1.19 \mathrm{ng} \mathrm{m}^{-3}\right)$. The concentration trends in indoor PAHs for the exposed schools were as follows: S1 $\left(63.22 \pm 33.95 \mathrm{ng} \mathrm{m}^{-3}\right)>\mathrm{S} 2$ $\left(54.97 \pm 48.94 \mathrm{ng} \mathrm{m}^{-3}\right)>\mathrm{S} 3\left(44.27 \pm 28.40 \mathrm{ng} \mathrm{m}^{-3}\right)$. Meanwhile, comparative school C1 demonstrated the highest indoor PAH concentration $\left(13.09 \pm 8.93 \mathrm{ng} \mathrm{m}^{-3}\right)$, followed by schools C2 (4.65 $\left.\pm 0.77 \mathrm{ng} \mathrm{m}^{-3}\right)$ and C3 $\left(4.24 \pm 1.14 \mathrm{ng} \mathrm{m}^{-3}\right)$.
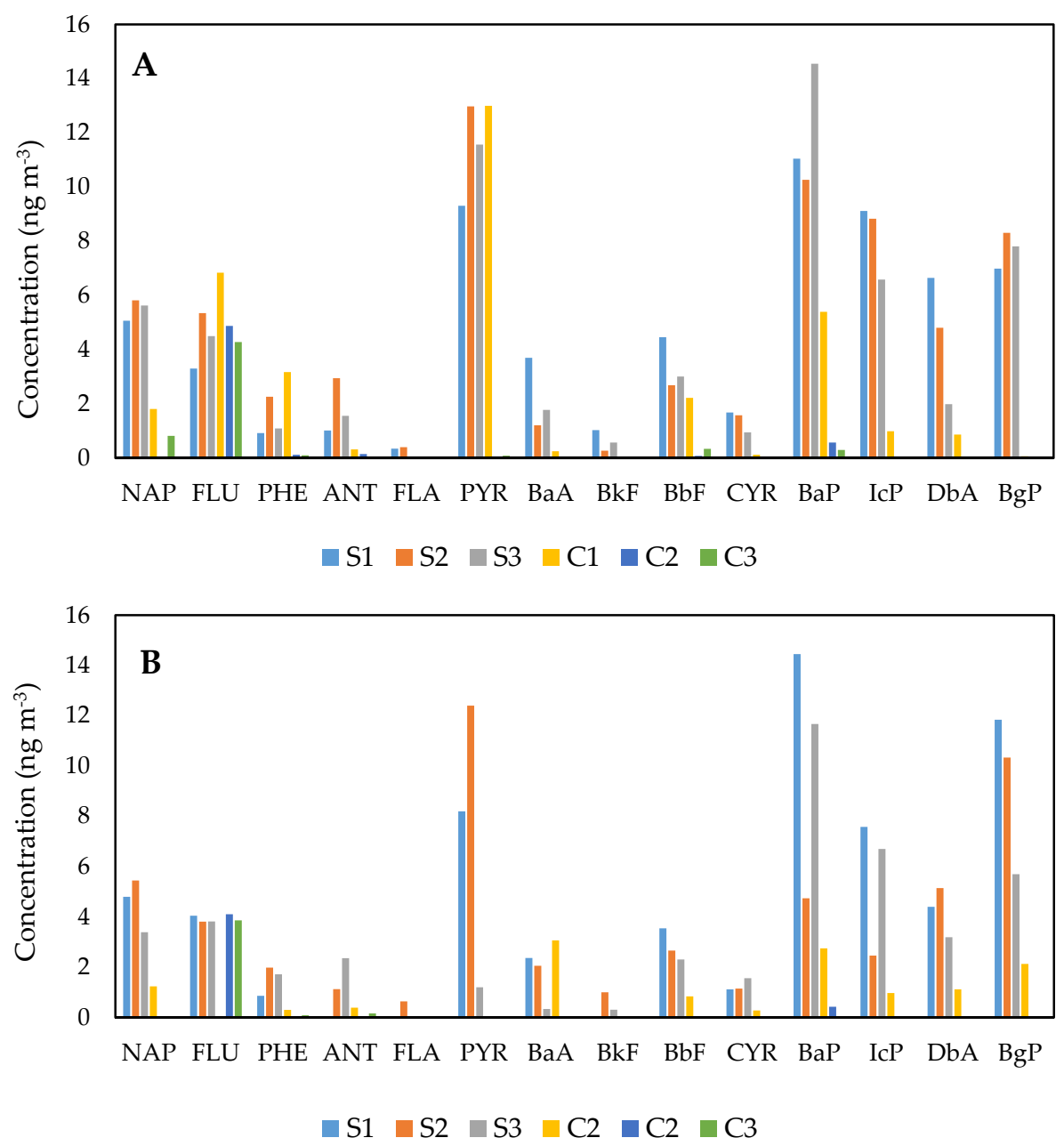

Figure 2. Distribution of polycyclic aromatic hydrocarbon (PAH) species in $\mathrm{PM}_{2.5}$ samples ((A): outdoor; (B): indoor).

In general, the distribution of individual PAHs was strongly dominated by the species of heavy-molecular-weight (HMW) PAHs, structured by four to six rings (Figure S1, Supplementary Materials). Schools C2 and C3 showed a contrasting finding; however, the low-molecular-weight (LMW) PAHs dominated the total concentration of PAHs relative to HMW PAHs. The outdoor LMW PAH concentrations of the three schools were $5.15 \pm 0.52$, $5.19 \pm 1.16$ and $16.38 \pm 11.67 \mathrm{ng} \mathrm{m}^{-3}$, respectively. The findings also depicted that the ACY and $\mathrm{ACP}$ were barely undetected by the instrument due to the low concentration present in all samples. The majority of HMW organisms, especially in schools C2 and C3, were present in small and intense concentrations. $\mathrm{BaP}$ and PYR were the most prominent species in particulate PAH samples for all the exposed schools, with concentrations exceeding $10.00 \mathrm{ng} \mathrm{m}^{-3}$. Besides, PYR was also the highest species found in the outdoor samples of school C1. The higher fraction of HMW PAHs could be influenced by the degree of solvent extraction efficiency [55]. In this study, dichloromethane and n-hexane had similar 
polarity properties as the HMW PAHs, thus favouring the excellent extraction efficiency of the heavier PAH component.

On the other hand, particulate PAHs measured at schools C2 and C3 were highly influenced by FLU species in outdoor and indoor samples, with a concentration of $4.00 \mathrm{ng} \mathrm{m}^{-3}$. The results specifically demonstrated that schools within a distance of $5 \mathrm{~km}$ from the industrial areas were subject to higher PAH concentrations relative to comparative schools. In the outdoor samples, the results also revealed a higher degree of PAHs than the indoor samples. Traffic emissions, idling vehicles during school dismissals and parking could lead to this condition [56]. In addition, the location of air-sampling pumps in the shielded environment in the classroom (i.e., doors and windows were closed during school hours) may be the justification for the low concentration of indoor PAHs [57].

The PAH concentration in the research area was higher than in a study by Di Gilio et al., as the indoor concentration was up to $2.36 \mathrm{ng} \mathrm{m}^{-3}$ at a school near the steel industrial area [58]. BbF, BgP, IcP, BkF, and DbA species were identified as the most abundant constituents in that study, which was scientifically known as a proxy for traffic and coke oven emissions. Meanwhile, at the two primary schools in North Portugal, the industrial air pollutant and traffic exposure caused elevated PAH levels, with values of 20.00 and 48.00 $\mathrm{ng} \mathrm{m}^{-3}$ [59]. In a school dormitory in an urban area of Tehran, Hassanvand et al. reported higher indoor and outdoor PAH concentration levels of 281.25 and $361.75 \mathrm{ng} \mathrm{m}^{-3}$, respectively [60]. The researchers eloquently mentioned that PHE, FLU, BaA, CYR and BgP were the most abundant PAH species, contributing significantly to fuel combustion activities (traffic and domestic heating emissions). Meanwhile, a school in Beijing demonstrated a higher PAH concentration ( $36.83 \mathrm{ng} \mathrm{m}^{-3}$ ) than the comparative schools, heavily dominated by ACY and FLA species [61].

Several subsequent studies on petrochemical air pollutant exposure have reported a higher PAH concentration than this present study. In a township within $10 \mathrm{~km}$ of the largest petrochemical complex in Taiwan, research by Yuan et al. found a higher PAH concentration, with an average PAH concentration of $15.20 \pm 15.18 \mu \mathrm{g} \mathrm{g}^{-1}$ [11]. BbF, FLA, $\mathrm{PYR}, \mathrm{BaP}, \mathrm{BgP}$ and IcP were the most prominent $\mathrm{PAH}$ species and could be emitted from oil refinery plants and coal power plants. The concentration of particulate PAHs $\left(\mathrm{PM}_{10}\right)$ from petrochemical-related factories in the Niger Delta, Nigeria, meanwhile, was $9.2 \mu \mathrm{g} \mathrm{m}^{-3}$ [62]. Similarly, in a petrochemical industrial complex in Ulsan, Korea, the PAH concentration obtained in road dust was $55.33 \pm 15.83 \mu \mathrm{g} \mathrm{g}^{-1}$, which was comparatively higher than the current study [13]. The study eloquently defined that the ring number distribution of PAHs in the petrochemical area was close to a heavily trafficked area, possibly because of the similarity in pollution sources. A study by Bozlaker et al. in Turkey, however, showed that the comparable concentration of PAHs (particulate and gas) varied in summer from 7.30 to $44.80 \mathrm{ng} \mathrm{m}^{-3}$ [14].

\subsection{Source Diagnostic Ratio}

The diagnostic ratio of the analysis source determined the possible sources by contrasting parent $\mathrm{PAH}$ ratios with frequently found $\mathrm{PAH}$ emissions (Figure S2, Supplementary Materials). The ratio of LMW/HMW PAHs was shown by the anthropogenic source apportion index, with values lower than 1 indicating pyrogenic emissions [63]. The ANT/(ANT + PHE) ratio was also an anthropogenic source indicator for PAH emissions, with values less than 0.1 suggesting a petrogenic source. In contrast, any value greater than $0.1 \mathrm{implies}$ a pyrogenic source [64]. Pyrogenic sources were possibly correlated with around $89.5 \%$ $(n=17)$ samples from the exposed school. The petrogenic source was an IcP/(Icp + BgP) ratio of less than 0.2 , and the fuel combustion source is denoted by a value ranging from 0.2 to $0.5[65]$.

A diagnostic ratio value that is higher than 0.5 indicates combustion of grass, wood or coal. The data specifically showed that all classes, except comparative school C1, which had a mean ratio of 0.46 , were predominantly grass-, wood- or coal-combustion-sourced. 
Relatively, exposed school S1 had the highest sample number $(n=7,63.6 \%)$ originating from fuel combustion.

In comparison, coal combustion and vehicular emissions can be distinguished by $\mathrm{BaA} / \mathrm{CYR}$ [65]. A value of 0.2 and 0.35 denoted coal combustion, while vehicular emissions were responsible for a value greater than 0.35 . The ratio indicated that the concentration of PAHs could have been caused by coal combustion, with 10 of the exposed school samples providing a large pollution source tracer. However, the majority of the samples were predominantly from traffic pollution. A diagnostic ratio of $\mathrm{BaA} /(\mathrm{BaA}+\mathrm{CYR})$ was proposed by Yunker et al. for the determination of the PAH emission source [66]. The ratio value of the petrogenic source was less than 0.2 , while that of the mixed source was between 0.2 and 0.35 . The contribution of combustion activity was demonstrated by a ratio larger than 0.35 . The petrogenic source denominated five samples of the exposed school based on the analysis. In contrast, the mixed source may emit two samples, and the remainder of the samples $(70.8 \%)$ may be released from the combustion activity.

Two vital anthropogenic sources contributed to air emissions in traffic, gasoline and diesel, comprising multiple constituents with congeners of high-molecular-weight PAHs. According to Fang et al., it is possible to use a diagnostic ratio formulated with FLU/(FLU + PYR) to discriminate between two origins of traffic emissions having a value less than 0.5 , suggesting the origin of gasoline [67]. On the other hand, a value greater than 0.5 means a source is diesel-combusted. Diesel emissions $(93.3 \%, n=14)$ were the major influence for the comparative schools, while 100\% samples of schools S2 and S3 were suspected of containing a gasoline marker, which may be contributed positively by heavy-duty vehicles passing by. Comparative schools are situated less than $50 \mathrm{~m}$ from the main road frequently used by palm oil lorries owned by the nearby plant oil plantation.

The exposed schools had a higher percentage of gasoline emissions, primarily due to heavy-duty vehicles (i.e., diesel-powered trucks) from the midstream area of the logistics hub of the petrochemical industry, contributing to the FLU/(FLU + PYR) diagnostic ratio. Gasoline combustion was also abundantly present in the samples of schools S1 and S2. The schools were less than $100 \mathrm{~m}$ from the main road and had a higher fraction of PAHs with a heavy molecular weight. This result was parallel to $[5,42,68]$, as light- and medium-duty tailpipe vehicles contribute to a higher concentration of heavy congener PAH emissions. Lin et al. suggested that automobiles powered by gasoline contribute to PAHs of medium and high sub-atomic weight [69].

Furthermore, diesel-fuelled vehicles have also been correlated with lower PAH percentages. This study's findings suggested that PAH sources may come from emissions from the oil and gas industry and traffic, wood, grass or coal combustion. A similar finding was reported in a previous study [11], as the location near a petrochemical complex was predominantly sourced from coal combustion based on the BaA/(BaA + CYR) diagnostic ratio measured at 0.67 . In addition, it was proposed that the bituminous coal used in the petrochemical complex, in particular PYR, $\mathrm{BaP}$ and $\mathrm{BbF}$, could emit a higher proportion of four- and five-ring PAHs.

\subsection{Principal Components Analysis (PCA)}

Three significant major principal components (PCs) for PAH emissions with a value above 1 were discovered by PCA, accounting for $75.06 \%$ variability data of the exposed schools. The contributing emission factors from the PCA of 28 samples of exposed schools and 18 samples of comparative schools are shown in Table 2. The hefty contribution of $\mathrm{NaP}$, FLU, PYR, BbF, CYR, IcP and BgP was defined by PC1, with a total variance of $45.12 \%$. $\mathrm{BbF}, \mathrm{CYR}, \mathrm{IcP}$ and $\mathrm{BgP}$ were indicative species for vehicle exhaust emissions [42,70]. Some studies have identified the emission of coke ovens as being supported by NAP, $\mathrm{BgP}$ and IcP [71,72]. Petroleum combustion is indicated by a higher fraction of HMW species, especially $\mathrm{BbF}$, IcP and $\mathrm{BgP}$ [73]. Meanwhile, $14.48 \%$ of the overall variation was clarified by $\mathrm{PC} 2$, primarily weighted by $\mathrm{BkF}, \mathrm{BaA}$, and FLA. As a tracer for diesel emissions, the three species in PC2 were identified [71]. PC3 had a difference of $15.10 \%$ and had heavy 
ANT loading and moderate PHE and DbA loading. The superiority of ANT, PHE and DbA [74] was represented by wood combustion behaviour. Vehicular traffic and industrial pollution may be positively attributed to the mixture of PC1 and PC2.

Table 2. Principal components analysis with varimax rotation.

\begin{tabular}{|c|c|c|c|c|c|}
\hline $\begin{array}{c}\text { Principal } \\
\text { Component (PC) }\end{array}$ & Species & $\begin{array}{l}\text { Factor } \\
\text { Loading }\end{array}$ & Eigenvalue & Variability (\%) & Source \\
\hline \multirow{8}{*}{$\begin{array}{c}\text { PC1 } \\
\text { Exposed schools }\end{array}$} & NAP & 0.824 & \multirow{8}{*}{7.201} & \multirow{8}{*}{45.120} & \multirow{8}{*}{$\begin{array}{l}\text { Vehicle and } \\
\text { coke oven }\end{array}$} \\
\hline & FLU & 0.829 & & & \\
\hline & PYR & 0.741 & & & \\
\hline & $\mathrm{BbF}$ & 0.827 & & & \\
\hline & CYR & 0.859 & & & \\
\hline & $\mathrm{IcP}$ & 0.889 & & & \\
\hline & $\mathrm{BgP}$ & 0.804 & & & \\
\hline & $\mathrm{BaP}$ & 0.630 & & & \\
\hline \multirow{5}{*}{$\begin{array}{c}\text { PC2 } \\
\text { Exposed schools }\end{array}$} & $\mathrm{BkF}$ & 0.828 & \multirow{5}{*}{1.782} & \multirow{5}{*}{14.836} & \multirow{5}{*}{ Gasoline } \\
\hline & FLA & 0.728 & & & \\
\hline & $\mathrm{BaA}$ & 0.758 & & & \\
\hline & $\mathrm{BbF}$ & 0.293 & & & \\
\hline & $\mathrm{BaP}$ & 0.233 & & & \\
\hline \multirow{5}{*}{$\begin{array}{c}\text { PC3 } \\
\text { Exposed schools }\end{array}$} & ANT & 0.948 & \multirow{5}{*}{1.526} & \multirow{5}{*}{15.103} & \multirow{5}{*}{$\begin{array}{c}\text { Wood com- } \\
\text { bustion, } \\
\text { diesel }\end{array}$} \\
\hline & PHE & 0.700 & & & \\
\hline & $\mathrm{DbA}$ & 0.558 & & & \\
\hline & NAP & 0.341 & & & \\
\hline & PYR & 0.335 & & & \\
\hline \multirow{6}{*}{$\begin{array}{c}\text { PC1 } \\
\text { Comparative } \\
\text { schools }\end{array}$} & PHE & 0.853 & \multirow{6}{*}{7.130} & \multirow{6}{*}{47.040} & \multirow{6}{*}{ Vehicle } \\
\hline & PYR & 0.931 & & & \\
\hline & $\mathrm{BbF}$ & 0.938 & & & \\
\hline & $\mathrm{BaP}$ & $\begin{array}{l}0.900 \\
0.907\end{array}$ & & & \\
\hline & $\mathrm{IcP}$ & 0.918 & & & \\
\hline & $\mathrm{BgP}$ & 0.832 & & & \\
\hline PC2 & $\mathrm{BaA}$ & 0.941 & \multirow{3}{*}{2.857} & \multirow{3}{*}{27.27} & \multirow{3}{*}{ Diesel } \\
\hline \multirow{2}{*}{$\begin{array}{l}\text { Comparative } \\
\text { schools }\end{array}$} & $\mathrm{BgP}$ & 0.954 & & & \\
\hline & CYR & 0.714 & & & \\
\hline \multirow{3}{*}{$\begin{array}{c}\text { PC3 } \\
\text { Comparative } \\
\text { schools }\end{array}$} & ANT & 0.977 & \multirow{3}{*}{1.080} & \multirow{3}{*}{9.34} & \multirow{3}{*}{$\begin{array}{l}\text { Wood com- } \\
\text { bustion }\end{array}$} \\
\hline & NAP & 0.231 & & & \\
\hline & FLU & 0.258 & & & \\
\hline
\end{tabular}

On the other hand, three PCs were greatly derived from the same study, with $83.66 \%$ variance in the dataset of the comparative schools. With $47.04 \%$ of the overall variation, the first identified PC clarified the dominant contribution of six species (PHE, PYR, BbF, BaP, $\mathrm{IcP}$ and $\mathrm{DbA}$ ). Meanwhile, with $27.27 \%$ data variance, the high loadings of $\mathrm{BaA}, \mathrm{BgP}$ and CYR distinguished PC2. PC3 accounted for $9.34 \%$ of the overall variation, with heavy ANT loading and poor NAP and FLU loading. The activities of vehicle emissions (PC1), diesel combustion (PC2) and wood combustion (PC3) were better represented in comparative schools by the profile of PAHs.

\subsection{Health Risk Assessment}

Generally, exposed school $\mathrm{S} 1$ showed the highest TEQ values $\left(20.01 \mathrm{ng} \mathrm{m}^{-3}\right)$, followed by S3 (16.89 $\mathrm{ng} \mathrm{m}^{-3}$ ) and S2 (13.69 $\mathrm{ng} \mathrm{m}^{-3}$ ) (Table S4). The TEQ values for comparative schools C1, C2, and C3 were 5.51, 0.54 and $0.21 \mathrm{ng} \mathrm{m}^{-3}$, respectively. A similar finding was observed in two elementary schools in Portugal, with TEQ values reaching up to $22.00 \mathrm{ng} \mathrm{m}^{-3}$ [75]. Besides, it was found that TEQ values in this study were higher than in studies reported in the urban city of Kuala Lumpur, i.e., 640.01 and $266.27 \mathrm{pg} \mathrm{m}^{-3}$, 
respectively [5,76]. Oliveira et al. mentioned that Asian schools had higher TEQ values (range: $4.70-49.4 \mathrm{ng} \mathrm{m}^{-3}$ ) than European schools (range: 0.04-29.8 $\mathrm{ng} \mathrm{m}^{-3}$ ) [6].

On average, BaP contributed over $50 \%$ of TEQ values, thus explaining this congener's predominant role in assessing the cancer risk due to PAH exposure [76]. Meanwhile, DbA portrayed the second-highest contributor to TEQ values ranging between $0.93 \%$ and $33.86 \%$. Furthermore, the DbA congener predominantly contributed up to $69 \%$ for school C3, and the rest of the schools had an average percentage TEF of less than $50 \%$. Oliveira et al. also identified that $\mathrm{BaP}$ and $\mathrm{DbA}$ were the most influential contributors to TEQ values in the health risk assessment [59].

Based on the ILCR model proposed by USEPA, the cancer risk due to exposure to PAHs through inhalation was determined [48]. The exposed children relatively had a substantially higher cancer risk than the comparative groups. It can be arranged in increasing order: C3 $\left(1.37 \times 10^{-8}\right)<\mathrm{C} 2\left(3.62 \times 10^{-8}\right)<\mathrm{C} 1\left(3.81 \times 10^{-7}\right)<\mathrm{S} 2\left(9.28 \times 10^{-7}\right)<\mathrm{S} 3$ $\left(1.09 \times 10^{-6}\right)<\mathrm{S} 1\left(1.29 \times 10^{-6}\right)$. Differences in body weight, physiology and variation in PAH exposure in individuals contribute to the uncertainty in evaluating health risks [47]. Hence, a more precise cancer risk estimation of PAH inhalation was obtained through Monte Carlo simulation, as depicted in Figure 3. The mean value of the simulated probability cancer risk for the exposed and comparative schools was $1.20 \times 10^{-6}$ and $8.38 \times 10^{-8}$, respectively. Both mean values show similarity to the actual generated ILCR in SPSS software $\left(1.13 \times 10^{-6}\right.$ and $\left.1.6 \times 10^{-7}\right)$. The 95th percentiles of the ILCR calculated the risk for the exposed and comparative populations as $2.22 \times 10^{-6}$ and $2.95 \times 10^{-7}$, respectively.

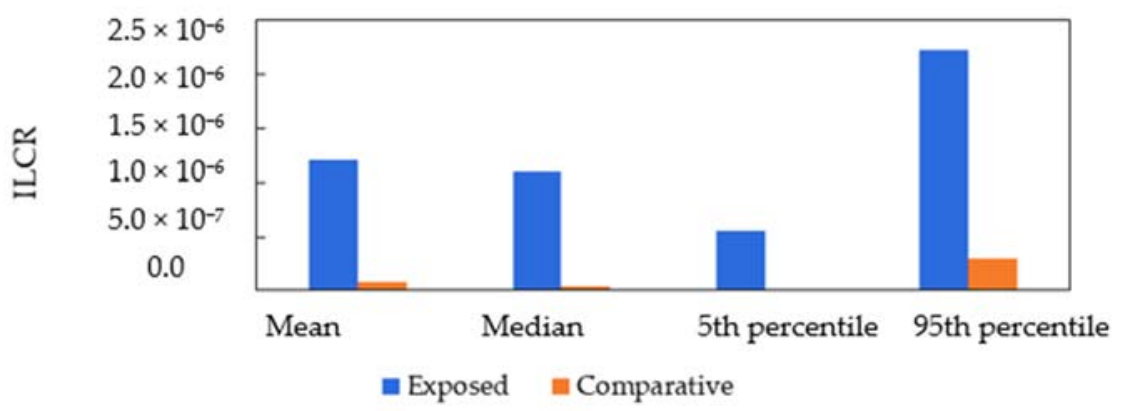

Figure 3. Probabilistic distribution of incremental lifetime cancer risk (ILCR) for exposed and comparative children.

The ILCR for the exposed children exceeds the acceptable risk limit of the USEPA reference and denotes a non-negligible risk [48]. The estimated carcinogen risk in this study for the exposed group was notably higher than two recent local studies in Kuala Lumpur (the year 2014: $3.32 \times 10^{-8}$; the year 2019: $2.64 \times 10^{-8}$ ), which was predominantly contributed by traffic emission $[5,76]$. Meanwhile, the magnitude of the ILCR for comparative schools was relatively lower than the risk calculated in elementary school children in Portugal, between $1.0 \times 10^{-8}$ to $5.0 \times 10^{-8}$ [75]. Oliveira et al. also eloquently concluded that Asian children are exposed to a higher magnitude of the ILCR $\left(1.3 \times 10^{-6}\right.$ to $\left.5.4 \times 10^{-5}\right)$ as compared to European children $\left(5.9 \times 10^{-9}\right.$ to $\left.1.1 \times 10^{-8}\right)$ [6]. Moreover, exposure to PAHs originating from vehicles, biomass, coal combustion and petroleum combustion increased the ILCR values to $2.1 \times 10^{-5}$ for children in Ulaanbaatar City, Mongolia [77]. Drastic environmental health control measures are required to effectively mitigate the non-negligible cancer risks due to PAH exposure [78].

Sensitivity analysis disclosed the most persuasive variable for the carcinogenic risk due to PAH inhalation. For the exposed group, the children's body weight $(-0.78)$ and the PAH concentration in the TEQ value (0.42) were the most influential determinants in the ILCR estimation (Figure 4A). A negative value of correlation shows that the increase in the predictor is related to a decrease in the ILCR prediction. Meanwhile, the TEQ value in the comparative dataset contributed about $66.7 \%$ variance of the risk output (Figure $4 \mathrm{~B}$ ). Simi- 
larly, the body weight of children in the comparative area had an antagonistic relationship $(-0.19)$, which is consistent with health risk assessment studies $[51,79,80]$.
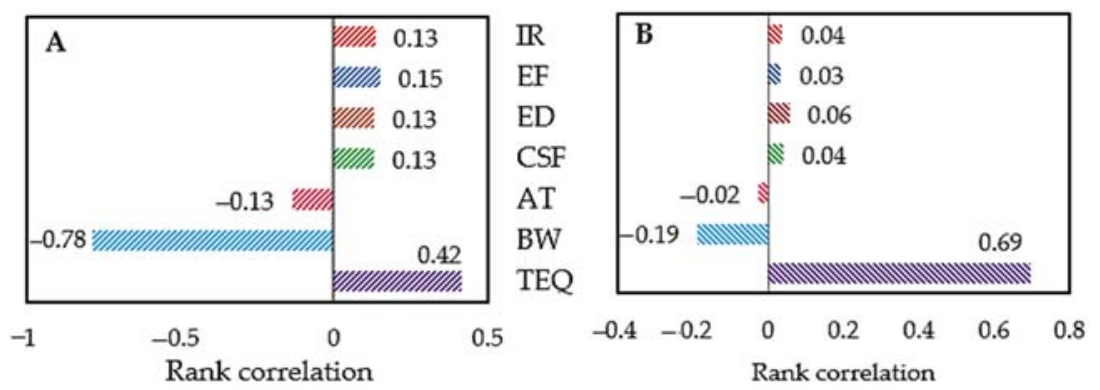

Figure 4. Sensitivity analysis of carcinogenic risk for exposed children (A) and comparative children $(\mathbf{B})$.

\subsection{Individual Factors in DNA Damage}

The tail moment of the exposed group (27.20 \pm 8.21$)$ was significantly longer than the value recorded in comparative school children $(21.03 \pm 4.88)$. The respondents from school S2 had the highest amount of DNA damage (31.89 \pm 11.28$)$ compared to children in other schools. On the other hand, the shortest tail moment, $20.43 \pm 5.34$, was shown by children in school $\mathrm{C} 1$. When statistically evaluated by one-way ANOVA, the result indicated that the exposed group had more substantial DNA damage than the comparative group (Table S5). Interestingly, this result was higher than in previous studies [22,31], when it was found that children living in proximity to the petrochemical industry in Mexico had an olive moment of $9.52(8.65,10.48)$ and $8.3(3.1-16.8)$, respectively. This disparity may be attributed to the different cellular samples used (lymphocytes vs. buccal epithelial cells) and the broader age span of children (6 to 12 years old).

Using independent $t$-test and one-way ANOVA, the individual tail moment variables were stratified and compared. The most significant factors for the comparative group were the age factor and mosquito coil use, according to Table 3. Compared to children aged 10 and 11 years, children aged 9 years had the shortest comet tail (exposed group: $25.40 \pm 4.12$; comparative group: $18.44 \pm 3.38$ ). In comparison, there was a significantly larger tail moment $(27.24 \pm 7.34)$ for children who lived with smoking family members than for children who were not exposed to cigarette smoke. In comparison, there was a considerably longer tail moment $(27.41 \pm 7.33)$ for grilled food users than for children who ate grilled food less regularly $(27.08 \pm 6.16)$. Interestingly, children who were exposed to mosquito coil pollutants, especially in the comparative community (22.27 \pm 4.32 vs. $20.20 \pm 4.20)(p<0.05)$, had a slightly higher tail moment value.

Confounding factors such as exposure to tobacco smoke and age can interfere with the sensitive comet assay outcome [81]. A recent research by Aksu et al., for instance, found that DNA damage was more serious among smoking adults than in the control group, although no significant comparison was observed [82]. Cigarette smoke exposure among children has been seen to have a significant elevation in DNA damage [83,84]. Gajski et al. did not find any major effect of age on DNA damage among children, although it was found that gender had a statistical impact on the tail length, tail intensity and tail moment [85]. In comparison, 25 female children (50\%) were observed to have significantly higher comet parameters than the male ones [85]. Recent research found that a group of male children living near a waste incinerator had more severe DNA damage than female children with a high heavy metal exposure burden [86].

The body mass index (BMI) did not influence the outcome of DNA damage in this current research. Overweight and underweight children, however, had a more extended tail moment than typical-BMI children. The finding agreed with a previous study [87], which confidently showed that a higher BMI among the population of healthy Swedish youngsters resulted in more severe DNA damage. As a result of the formation of reactive oxygen species and lipid peroxidation, excessive body fat has been postulated to impede 
DNA stability [88]. Regarding the intake of grilled foods, it was confirmed that they contain carcinogenic substances (i.e., PAHs) [89] and that they are associated with altering the structure of DNA adducts and may cause DNA damage [90]. Meanwhile, intake of fruit, vegetables and health supplements could suppress DNA damage [91]. The deficiency of micronutrients, such as vitamin C, vitamin E, zinc and antioxidants, could also escalate the risk of deformation of DNA strands and increase the chromosomal damage incidence [92].

Table 3. Comparison of individual factors in the tail moment among children.

\begin{tabular}{|c|c|c|c|c|}
\hline \multirow[t]{2}{*}{ Variables } & \multicolumn{2}{|c|}{ Exposed Group $(n=85)$} & \multicolumn{2}{|c|}{ Comparative Group (120 } \\
\hline & Mean \pm SD & $p$-Value & Mean \pm SD & $p$-Value \\
\hline \multicolumn{5}{|l|}{ Age (year) } \\
\hline 9 & $25.40 \pm 4.12$ & 0.409 & $18.44 \pm 3.38$ & $0.005 *$ \\
\hline 10 & $26.70 \pm 6.07$ & & $21.98 \pm 4.50$ & \\
\hline 11 & $27.96 \pm 7.38$ & & $20.46 \pm 4.08$ & \\
\hline \multicolumn{5}{|c|}{ Exposure to tobacco smoke } \\
\hline Yes & $27.24 \pm 7.34$ & 0.915 & $20.86 \pm 474$ & 0.674 \\
\hline No & $27.08 \pm 6.31$ & & $20.52 \pm 3.91$ & \\
\hline \multicolumn{5}{|l|}{ Grilled food } \\
\hline Yes & $27.41 \pm 7.33$ & 0.804 & $21.14 \pm 4.49$ & 0.354 \\
\hline No & $27.08 \pm 6.16$ & & $20.37 \pm 4.17$ & \\
\hline \multicolumn{5}{|l|}{ Supplement } \\
\hline Yes & $26.98 \pm 6.76$ & 0.646 & $20.53 \pm 4.05$ & 0.584 \\
\hline No & $27.60 \pm 6.56$ & & $21.06 \pm 4.92$ & \\
\hline \multicolumn{5}{|c|}{ Mosquito coil } \\
\hline Yes & $30.05 \pm 7.11$ & 0.085 & $22.27 \pm 4.32$ & 0.034 * \\
\hline No & $26.71 \pm 6.46$ & & $20.20 \pm 4.20$ & \\
\hline \multicolumn{5}{|c|}{ Open burning } \\
\hline Yes & $26.15 \pm 6.33$ & 0.350 & $20.56 \pm 4.40$ & 0.766 \\
\hline No & $27.53 \pm 6.73$ & & $20.79 \pm 4.23$ & \\
\hline
\end{tabular}

* $p$-Value is significant at level 0.001 .

Various scientific studies have shown the adverse impact of insect repellent and incense smoke exposure through animal and epidemiological studies [93-95]. Liu et al. found that a large concentration of volatile organic compounds (VOCs), PAHs, aldehydes and fine particles, which pose an acute and chronic health risk, could be generated by mosquito coils [96]. Besides, mosquito coils are the most toxic insect repellents than mat and liquid repellents [93] due to a higher lipid peroxidation response and increased freeradical substances that can alter the cell membrane and cause damage to DNA [95]. In this current study, DNA damage in buccal epithelial cells, especially among the comparative population, was significantly affected by mosquito coil exposure. An in vitro study by Szeto et al. confirmed the finding, as they discovered that insect repellents (i.e., incense burning) could cause degradation of the DNA strands in human lymphocytes [97]. The indoor air toxins of mosquito coils were also associated with lung cancer incidence [98,99].

\subsection{Relationship between Tail Moment with PAH Exposure and Other Risk Factors}

Individual factor and environmental PAHs exposure were assessed individually on how diverse the factors contributed to DNA damage among children. Simple linear regression demonstrated a highly significant relationship between PAHs concentration and DNA damage. Furthermore, the analysis also revealed a significant association between age, BMI, and open burning on DNA damage (Table S6, Supplementary Materials). Multiple linear regression was further performed to determine the best measure of the dependent variables in order to boost statistical aid. The statistical equations indicated that the tail moment increased with each increased unit of total outdoor PAHs and carcinogens, a decreased unit of non-carcinogenic PAHs and frequent open burning (Table 4). The first prediction model consists of two important variables (i.e., total outdoor PAHs and open burning), with $F(3,206)=9.643, p<0.0001$ and adjusted $R^{2}=0.110$, which significantly affect the 
tail moment. A combination of two variables suggested that $11.0 \%$ of the variability of the tail moment after confounder adjustment was clarified by the model. Similarly, the second model includes two significant variables (outdoor PAH concentration carcinogen and open burning), with $\mathrm{F}(4,223)=9.039, p<0.0001$ and adjusted $\mathrm{R}^{2}=0.124 ; 12.4 \%$ of the tail moment variance was described. Due to the violation of the $p$-value, non-carcinogenic outdoor PAHs, age, BMI and mosquito coil were excluded from the model.

Table 4. Prediction models of the tail moment after controlling all confounders.

\begin{tabular}{|c|c|}
\hline Model & $\operatorname{Adj} R^{2}$ \\
\hline $\begin{array}{c}\text { Model } 1 \\
\text { Tail moment }=12.892+0.054 \text { (total outdoor PAHs)-2.415 (open burning) }\end{array}$ & 0.110 \\
\hline $\begin{array}{c}\text { Model } 2 \\
\text { Tail moment }=14.120+0.170(\text { carcinogen outdoor PAHs })-1.870 \text { (open burning })\end{array}$ & 0.124 \\
\hline $\begin{array}{c}\text { Model } 3 \\
\text { Tail moment }=13.345+0.076 \text { (total indoor PAHs) }-2.190 \text { (open burning) }\end{array}$ & 0.115 \\
\hline $\begin{array}{c}\text { Model } 4 \\
\text { Tail moment }=15.468+0.187 \text { (carcinogen indoor PAHs) }-2.328 \text { (open burning) }\end{array}$ & 0.127 \\
\hline
\end{tabular}

The significant variables for estimating the tail moment of $\mathrm{F}(5,204)=7.072, p<0.0001$ and adjusted $\mathrm{R}^{2}=0.148$ were the total concentration of indoor PAHs and open burning. After controlling all the possible confounders, the third model described approximately $14.8 \%$ of the variance of the tail moment. The fourth model, containing the concentration of carcinogenic indoor PAHs and open burning, which substantially predicted DNA damage in the buccal epithelial cell, with adjusted $R^{2}=0.127$, was also obtained from the multivariate analysis. In other words, by the interaction of indoor PAH emissions and open burning, this model substantially explained a $12.7 \%$ variation of the tail moment. This result was in agreement with Gamboa et al., in which more severe DNA damage was found among Mexican children living close to the industrial area of oil extraction and correlated with chronic PAH pollution exposure [100]. In that analysis, one of the carcinogenic PAH species, BkF, was reported as significantly higher $\left(47.29 \pm 10.65\right.$ vs. $\left.17.36 \pm 3.79 \mathrm{ng} \mathrm{m}^{-3}\right)$ relative to regions without oil extraction activity.

Jasso-Pineda et al. also revealed more significant DNA damage in a population of children living in a household that used biomass combustion and was strongly associated with internal PAH exposure, specifically urinary 1-hydroxypyrene (1-OHP) [20]. A stratified analysis by Sachez-Guerra et al. showed that excretion metabolite PAHs and DNA damage were significantly correlated, with DNA damage among children living near the petrochemical industry [31]. Likewise, Ruchirawat et al. eloquently illustrated a higher internal dose magnitude of PAH metabolites and DNA damage in urban children than in the comparative group [23]. In addition, a cross-sectional analysis in Kuala Lumpur, Malaysia, also showed a high risk of DNA injury and respiratory symptoms among children attending school near heavy traffic areas [101].

The common practice of domestic open burning of household waste was proposed to justify the higher incidence of respiratory disease in rural communities [102]. This research found that the practice of open burning is also statistically established as one of the causal factors for the higher occurrence of genotoxicity among children. Besides, it has been conclusively proven that a higher concentration of carcinogenic PAHs is generated by domestic open burning, especially during the dry season [103]. During school hours, the residential areas near the schools often burned waste, having a detrimental effect on air sampling. Therefore, public health issues will be caused by the illegal open-burning practice among the nearby population, especially during school hours. This leads to an unhealthy environment and may increase DNA damage among children.

In vitro studies have revealed synergism, additive or antagonism findings through the genotoxic potency of the PAH mixture [104-106]. The cytotoxicity and genotoxicity of a mixture of PAHs on HepG2 cells were researched in the year 2018 and disclosed an 
interesting finding [107]. It was found that the binary combination of carcinogenic BaP with non-carcinogen PAHs is cytotoxic; however, they do not have a genotoxic effect on the cells. The authors measured a decrease of $60 \%$ in chromosomal damage relative to a single $\mathrm{BaP}$ dose. The combination effect of $\mathrm{BaP}$ with $\mathrm{BbF}$ and $\mathrm{BaA}$ pairwise $\mathrm{PAHs}$ on the metabolic p53 pathway is synergistic [108]. Therefore, simultaneous inhalation of various congeners of PAHs has aggravating mechanistic effects on human health.

\section{Conclusions}

This present research concluded that sensitive receptors experience higher exposure to particulate PAHs in the exposed area. The results revealed that the highest concentration of total PAHs was reported at exposed school S2, with a value of $67.72 \pm 49.84 \mathrm{ng} \mathrm{m}^{-3}$, followed closely by school S1 $\left(64.64 \pm 44.85 \mathrm{ng} \mathrm{m}^{-3}\right)$ and school S3 $\left(61.60 \pm 39.74 \mathrm{ng} \mathrm{m}^{-3}\right)$. On the other hand, low PAH concentrations were recorded in comparative schools, especially in schools C2 $\left(5.93 \pm 0.59 \mathrm{ng} \mathrm{m}^{-3}\right)$ and C3 $\left(6.36 \pm 1.19 \mathrm{ng} \mathrm{m}^{-3}\right)$. The source diagnostic ratio and PCA analysis indicated that the source of PAHs could come from the petrochemical industry, traffic emission and also wood combustion. Monte Carlo simulation predicted that the 95th percentiles of the ILCR for the exposed and comparative populations were $2.22 \times 10^{-6}$ and $2.95 \times 10^{-7}$, respectively. Generally, the cancer risk due to PAH inhalation for the exposed children exceeds the acceptable risk limit of the USEPA reference and denotes a non-negligible risk. Sensitivity analysis disclosed the body weight of children and PAH concentrations in the air were the most persuasive variables to estimate a precise carcinogenic risk due to $\mathrm{PAH}$ exposure.

Comet assay microscopy analysis found that the exposed groups had a significantly higher tail moment than the comparative groups. The mean tail moment values were $27.20 \pm 8.21$ and $21.03 \pm 4.88$ for the exposed and comparative groups, respectively. Stratified analysis revealed that the age factor and exposure to mosquito coils greatly affect the tail moment. This research strongly suggested that DNA damage is significantly affected by particulate PAHs after controlling all possible confounding factors (e.g., demographic, socio-economic, lifestyle and tobacco smoke exposure) in both study design and statistical analysis. The result provided evidence that children living in close proximity to the industrial zone could be subject to greater levels of exposure to environmental PAHs and a higher risk of genotoxicity than children living in less polluted areas.

Moreover, as limited epidemiological studies have been performed on the relationship between industrial air pollution and genotoxicity among children in Southeast Asia, the knowledge gap has been successfully reduced. New genotoxicity models have been successfully established, which forecast exposure to PAHs as a valuable health impact assessment (HIA) tool. The findings will help understand the levels, distribution and sources of PAHs in educational institutions, providing insights into the governance of the living environment and children's well-being, particularly in the industrial area.

Supplementary Materials: The following are available online at https://www.mdpi.com/1660-4 601/18/5/2575/s1: Figure S1: Percentage distribution of outdoor and indoor PAHs according to the number of rings; Figure S2: Source diagnostic ratio; Table S1: Descriptive information about the schools' locations; Table S2: Correlation coefficient and limits of detection (LOD) of 16 priority PAHs; Table S3: Distribution of PAH species in $\mathrm{PM}_{2.5}$ samples; Table S4: Toxic equivalent concentration for PAH compounds; Table S5: The mean comparison tail moment among children; Table S6: Relationship between tail moment with PAH exposure and other risk factors.

Author Contributions: N.A.S.: writing—original draft and investigation. J.J.: writing-review and editing, conceptualisation and supervision. S.A.B.: validation and supervision. T.R.H.: writingreviewing and editing; M.T.L.: writing - review and editing, methodology and supervision. All authors have read and agreed to the published version of the manuscript.

Funding: This study was funded by the Universiti Putra Malaysia (project code: GP-IPS/2016/9504000). 
Institutional Review Board Statement: The study was conducted according to the guidelines of the Declaration of Helsinki and approved by the ethics committee for research involving human subjects, Universiti Putra Malaysia (JKEUPM Ref No. FPSK(EXP16) P101 and 29 June 2016).

Informed Consent Statement: Informed consent was obtained from all subjects involved in the study. Data Availability Statement: Not applicable.

Acknowledgments: The authors acknowledge the generous support and assistance from the Environmental Health Lab, Faculty of Medicine and Health Sciences, Universiti Putra Malaysia, and Laboratory 2146, Faculty of Science and Technology, Universiti Kebangsaan Malaysia. Special thanks to Anas Ahmad Jamhari and Haris Hafizal Abd Hamid for their technical support.

Conflicts of Interest: The authors declare no conflict of interest.

\section{References}

1. Ali, N. Polycyclic Aromatic Hydrocarbons (PAHs) in Indoor Air and Dust Samples of Different Saudi Microenvironments; Health and Carcinogenic Risk Assessment for the General Population. Sci. Total Environ. 2019, 696, 133995. [CrossRef]

2. Dai, Y.; Huo, X.; Cheng, Z.; Wang, Q.; Zhang, Y.; Xu, X. Alterations in Platelet Indices Link Polycyclic Aromatic Hydrocarbons Toxicity to Low-Grade Inflammation in Preschool Children. Environ. Int. 2019, 131, 105043. [CrossRef]

3. Huang, X.; Deng, X.; Li, W.; Liu, S.; Chen, Y.; Yang, B.; Liu, Q. Internal Exposure Levels of Polycyclic Aromatic Hydrocarbons in Children and Adolescents: A Systematic Review and Meta-Analysis. Environ. Health Prev. Med. 2019, 24, 50. [CrossRef] [PubMed]

4. Iwegbue, C.M.A.; Obi, G.; Uzoekwe, S.A.; Egobueze, F.E.; Odali, E.W.; Tesi, G.O.; Nwajei, G.E.; Martincigh, B.S. Distribution, sources and risk of exposure to polycyclic aromatic hydrocarbons in indoor dusts from electronic repair workshops in southern Nigeria. Emerg. Contam. 2019, 5, 23-30. [CrossRef]

5. $\quad$ Sulong, N.A.; Latif, M.T.; Sahani, M.; Khan, M.F.; Fadzil, M.F.; Mohd Tahir, N.; Mohamad, N.; Sakai, N.; Fujii, Y.; Othman, M.; et al. Distribution, sources and potential health risks of polycyclic aromatic hydrocarbons (PAHs) in $\mathrm{PM}_{2.5}$ collected during different monsoon seasons and haze episode in Kuala Lumpur. Chemosphere 2019, 219, 1-14. [CrossRef] [PubMed]

6. Oliveira, M.; Slezakova, K.; Delerue-matos, C.; Carmo, M.; Morais, S. Children environmental exposure to particulate matter and polycyclic aromatic hydrocarbons and biomonitoring in school environments: A review on indoor and outdoor exposure levels, major sources and health impacts. Environ. Int. 2019, 124, 180-204. [CrossRef]

7. World Health Organization (WHO). WHO Air Quality Guidelines for Particulate Matter, Ozone, Nitrogen Dioxide and Sulfur Dioxid; WHO: Geneva, Switzerland, 2006; Available online: http://apps.who.int/iris/bitstream/handle/10665/69477/WHO_SDE_ PHE_OEH_06.02_eng.pdf, sequence=1 (accessed on 14 June 2018).

8. Agency for Toxic Substances and Disease Registry (ATSDR). ATSDR's Substance Priority List. 2020. Available online: https: / / www.atsdr.cdc.gov/spl/index.html (accessed on 20 July 2020).

9. Abdel-shafy, H.I.; Mansour, M.S.M. A review on polycyclic aromatic hydrocarbons: Source, environmental impact, effect on human health and remediation. Egypt. J. Pet. 2016, 25, 107-123. [CrossRef]

10. Wang, Z.; Li, J.; Mu, X.; Zhao, L.; Gu, C.; Gao, H.; Ma, J.; Mao, X.; Huang, T. A WRF-CMAQ modeling of atmospheric PAH cycling and health risks in the heavy petrochemical industrialised Lanzhou valley, Northwest China. J. Clean Prod. 2021, 291, 125989. [CrossRef]

11. Yuan, T.; Shie, R.; Chin, Y.; Chan, C. Assessment of the levels of urinary 1-hydroxypyrene and air polycyclic aromatic hydrocarbon in $\mathrm{PM}_{2.5}$ for adult exposure to the petrochemical complex emissions. Environ. Res. 2015, 136, 219-226. [CrossRef]

12. Zhao, B.; Zhang, S.; Zhou, Y.; He, D.; Li, Y.; Ren, M.; Xu, Z.; Fang, J. Characterisation and quantification of PAH atmospheric pollution from a large petrochemical complex in Guangzhou: GC-MS/MS analysis. Microchem. J. 2015, 119, 140-144. [CrossRef]

13. Dong, T.T.T.; Lee, B.K. Characteristics, toxicity, and source apportionment of polycyclic aromatic hydrocarbons (PAHs) in road dust of Ulsan, Korea. Chemosphere 2009, 74, 1245-1253. [CrossRef] [PubMed]

14. Bozlaker, A.; Muezzinoglu, A.; Odabasi, M. Atmospheric concentrations, dry deposition and air-soil exchange of polycyclic aromatic hydrocarbons (PAHs) in an industrial region in Turkey. J. Hazard. Mater. 2008, 153, 1093-1102. [CrossRef]

15. WHO. Air Pollution and Child Health: Prescribing Clean Air. Summary; World Health Organization: Geneva, Switzerland, 2018; pp. 1-18.

16. Fan, R.; Wang, D.; Mao, C.; Ou, S.; Lian, Z.; Huang, S.; Lin, Q.; Ding, R.; She, J. Preliminary study of children's exposure to PAHs and its association with 8-hydroxy-2'-deoxyguanosine in Guangzhou, China. Environ. Int. 2012, 42, 53-58. [CrossRef]

17. Murawski, A.; Roth, A.; Schwedler, G.; Schmied-tobies, M.I.H.; Rucic, E.; Pluym, N.; Scherer, M.; Scherer, G.; Conrad, A.; Kolossa-Gehring, M. Polycyclic Aromatic Hydrocarbons (PAH) in Urine of Children and Adolescents in Germany-Human Biomonitoring Results of the German Environmental Survey 2014-2017 (GerES V). Int. J. Hyg. Environ. Health 2020, $226,113491$. [CrossRef]

18. Tang, C.S.; Lung, S.C.C.; Chang, T.Y.; Tu, H.H.; Chang, L.T. Investigation of Microenvironmental Exposures to Particle-Bound Polycyclic Aromatic Hydrocarbons for Elementary School Children. Int. J. Environ. Res. Public Health 2019, 16, 4390. [CrossRef]

19. Sopian, N.A.; Jalaludin, J. The application of biomarker in determining genotoxic potential of polyaromatic hydrocarbon exposure among children. Ann. Trop. Med. Public Health 2017, 10, 533-543. 
20. Jasso-pineda, Y.; Díaz-barriga, F.; Yáñez-estrada, L.; Pérez-vázquez, F.J.; Pérez-maldonado, I.N. DNA damage in Mexican children living in high-risk contaminated scenarios. Sci. Total Environ. 2015, 519, 38-48. [CrossRef]

21. Busso, T.; Carreras, H.; Amarillo, A.C. Exposure to polycyclic aromatic hydrocarbons in urban environments: Health risk assessment by age groups. Environ. Pol. 2014, 195, 157-162.

22. Pelallo-martınez, N.A.; Carrizales-ya, L.B.L.; Mart1, F. Genotoxic and Hematological Effects in Children Exposed to a Chemical Mixture in a Petrochemical Area in Mexico. Arch. Environ. Contam. Toxico. 2014, 67, 1-8. [CrossRef] [PubMed]

23. Ruchirawat, M.; Settachan, D.; Navasumrit, P. Assessment of potential cancer risk in children exposed to urban air pollution in Bangkok, Thailand. Toxicol. Lett. 2007, 168, 200-209. [CrossRef] [PubMed]

24. Zeng, Z.; Huo, X.; Wang, Q.; Wang, C.; Hylkema, M.N.; Xu, X. PM 2.5 -Bound PAHs Exposure Linked with Low Plasma Insulin-like Growth Factor 1 Levels and Reduced Child Height. Environ. Int. 2020, 138, 105660. [CrossRef]

25. Chen, L.; Hu, G.; Fan, R.; Lv, Y.; Dai, Y.; Xu, Z. Association of PAHs and BTEX Exposure with Lung Function and Respiratory Symptoms among a Nonoccupational Population near the Coal Chemical Industry in Northern China. Environ. Int. 2018, 120, 480-488. [CrossRef]

26. Poursafa, P.; Dadvand, P.; Mehdi, M.; Hajizadeh, Y.; Ebrahimpour, K.; Mansourian, M.; Pourzamani, H.; Sunyer, J.; Kelishadi, R. Association of Polycyclic Aromatic Hydrocarbons with Cardiometabolic Risk Factors and Obesity in Children. Environ. Int. 2018, 118, 203-210. [CrossRef]

27. Bortey-Sam, N.; Ikenaka, Y.; Akoto, O.; Nakayama, S.M.M.; Asante, K.A.; Baidoo, E.; Obirikorang, C.; Saengtienchai, A.; Isoda, N.; Nimako, C.; et al. Oxidative Stress and Respiratory Symptoms Due to Human Exposure to Polycyclic Aromatic Hydrocarbons (PAHs) in Kumasi, Ghana. Environ. Pollut. 2017, 228, 311-320. [CrossRef] [PubMed]

28. Da Silva, C.S.; Rossato, J.M.; Vaz Rocha, J.A.; Vargas, V.M. Characterisation of an area of reference for inhalable particulate matter $\left(\mathrm{PM}_{2.5}\right)$ associated with genetic biomonitoring in children. Mutat. Res. Genet. Toxicol. Environ. Mutagen. 2015, $778,44-55$. [CrossRef]

29. Ceretti, E.; Feretti, D.; Viola, G.C.V.; Zerbini, I.; Limina, R.M.; Zani, C.; Capelli, M.; Lamera, R.; Donato, F.; Gelatti, U. DNA Damage in Buccal Mucosa Cells of Pre-School Children Exposed to High Levels of Urban Air Pollutants. PLoS ONE 2014, 9, e96524. [CrossRef] [PubMed]

30. Sopian, N.A.; Jalaludin, J.; Mayusi, T.Z.A.T.; Latif, M.T. Increased Chromosomal Damage among Children in Proximity to Industrial Zone. Aerosol Air Qual. Res. 2020, 20, 944-955. [CrossRef]

31. Sánchez-Guerra, M.; Pelallo-Martínez, N.; Díaz-Barriga, F.; Rothenberg, S.J.; Hernández-Cadena, L.; Faugeron, S.; OropezaHernándeze, L.F.; Guaderrama-Díaz, M.; Quintanilla-Vega, B. Environmental polycyclic aromatic hydrocarbon (PAH) exposure and DNA damage in Mexican children. Mutat. Res. Genet. Toxicol. Environ. Mutagen. 2012, 742, 66-71. [CrossRef]

32. Kyrtopoulos, S.; Georgiadis, P.; Autrup, H.; Demopoulos, N.; Farmer, P.; Haugen, A.; Katsouyanni, K.; Lambert, B.; Ovrebo, S.; Sram, R.; et al. Biomarkers of genotoxicity of urban air pollution: Overview and descriptive data from a molecular epidemiology study on populations exposed to moderate-to- low levels of polycyclic aromatic hydrocarbons: The AULIS project. Mutat. Res. 2001, 496, 207-228. [CrossRef]

33. Hrelia, P.; Maffei, F.; Angelini, S.; Forti, G.C. A molecular epidemiological approach to health risk assessment of urban air pollution. Toxicol. Lett. 2004, 149, 261-267. [CrossRef]

34. Suhaimi, N.F.; Jalaludin, J. Biomarker as a Research Tool in Linking Exposure to Air Particles and Respiratory Health. BioMed Res. Int. 2015, 2015, 962853. [CrossRef] [PubMed]

35. Daud, S.A.M.; Jalaludin, J.; Sopian, N.A. Air pollutants exposure and frequency of micronuclei (MN) among primary school children nearby industrial Area. Malays. J. Med. Health Sci. 2018, 14, 56-62.

36. Kamaruddin, A.S.; Jalaludin, J.; Hamedon, T.R.; Hisamuddin, N.H. FeNO as a Biomarker for Airway Inflammation Due to Exposure to Air Pollutants among School Children Nearby Industrial Areas in Terengganu. Pertanika J. Sci. Technol. 2019, 27, 589-600.

37. Seifi, M.; Niazi, S.; Johnson, G.; Nodehi, V.; Yunesian, M. Exposure to ambient air pollution and risk of childhood cancers: A population-based study in Tehran, Iran. Sci. Total Environ. 2019, 646, 105-110. [CrossRef] [PubMed]

38. Jalaludin, J.; Noh, S.N.S.; Suhaimi, N.F.; Akim, A.M. Tumor necrosis factor-alpha as biomarkers of exposure to indoor pollutants among primary school children in Klang Valley. Am. J. Appl. Sci. 2014, 11, 1616-1630. [CrossRef]

39. Hisamuddin, N.H.; Jalaludin, J. Traffic Related Air Pollution and Its Impact on Respiratory Health among Children. Malays. J. Med. Health Sci. 2019, 15, 103-106.

40. Ceppi, M.; Biasotti, B.; Fenech, M.; Bonassi, S. Human population studies with the exfoliated buccal micronucleus assay: Statistical and epidemiological issues. Mutat. Res. Rev. Mutat. Res. 2010, 705, 11-19. [CrossRef]

41. Sinitsky, M.Y.; Druzhinin, V.G. The application of the cytokinesis-block micronucleus assay on peripheral blood lymphocytes for the assessment of genome damage in long-term residents of areas with high radon concentration. J. Radiat. Res. 2014, 55, 61-66. [CrossRef] [PubMed]

42. Khan, M.F.; Latif, M.T.; Lim, C.H.; Amil, N.; Jaafar, S.A.; Dominick, D.; Mohd Nadzir, M.S.; Sahani, M.; Tahir, N.M. Seasonal effect and source apportionment of polycyclic aromatic hydrocarbons in $\mathrm{PM}_{2.5}$. Atmos. Environ. 2015, 106, 178-190. [CrossRef]

43. Mirrezaei, M.A.; Orkomi, A.A. Gas flares contribution in total health risk assessment of BTEX in Asalouyeh, Iran. Process Safety Environ. Prot. 2020, 137, 223-237. [CrossRef] 
44. Nisbet, I.C.; LaGoy, P.K. Toxic equivalency factors (TEFs) for polycyclic aromatic hydrocarbons (PAHs). Regul. Toxicol. Pharmacol. 1992, 16, 290-300. [CrossRef]

45. Nadali, A.; Leili, M.; Bahrami, A.; Karami, M.; Afkhami, A. Phase distribution and risk assessment of PAHs in ambient air of Hamadan, Iran. Ecotox. Environ. Saf. 2021, 209, 111807. [CrossRef]

46. Othman, M.; Latif, M.T.; Jamhari, A.A.; Abd Hamid, H.H.; Uning, R.; Khan, M.F.; Mohd Nadzir, M.S.; Sahani, M.; Abdul Wahab, M.I.; Chan, K.M. Spatial distribution of fine and coarse particulate matter during a southwest monsoon in Peninsular Malaysia. Chemosphere 2021, 262, 127767. [CrossRef] [PubMed]

47. Ouyang, R.; Yang, S.; Xu, L. Analysis and risk assessment of $\mathrm{PM}_{2.5}$-bound PAHs in a comparison of indoor and outdoor environments in a middle school: A case study in Beijing, China. Atmosphere 2020, 11, 904. [CrossRef]

48. U.S. Environmental Protection Agency (USEPA). Exposure Factors Handbook: 2011 Edition; EPA/600/R-09/052F; National Center for Environmental Assessment: Washington, DC, USA, 2011. Available online: https://www.epa.gov/expobox/exposure-factorshandbook-chapter-6 (accessed on 5 February 2021).

49. Peng, C.; Chen, W.; Liao, X.; Wang, M.; Ouyang, Z.; Jiao, W.; Bai, Y. Polycyclic aromatic hydrocarbons in urban soils of Beijing: Status, sources, distribution and potential risk. Environ. Pol. 2011, 159, 802-808. [CrossRef] [PubMed]

50. Liu, Y.; Qin, N.; Liang, W.; Chen, X.; Hou, R.; Kang, Y.; Guo, Q.; Cao, S.; Duan, X. Polycycl. Aromatic hydrocarbon exposure of children in typical household coal combustion environments: Seasonal variations, sources, and carcinogenic risks. Int. J. Environ. Res. Public Health 2020, 17, 6520. [CrossRef]

51. Tarafdar, A.; Oh, M.J.; Nguyen-Phuong, Q.; Kwon, J.H. Profiling and potential cancer risk assessment on children exposed to PAHs in playground dust/soil: A comparative study on poured rubber surfaced and classical soil playgrounds in Seoul. Environ. Geochem. Health 2020, 42, 1691-1704. [CrossRef] [PubMed]

52. Gyori, B.M.; Venkatachalam, G.; Thiagarajan, P.S.; Hsu, D.; Clement, M. OpenComet: An automated tool for comet assay image analysis. Redox Biol. 2014, 2, 457-465. [CrossRef]

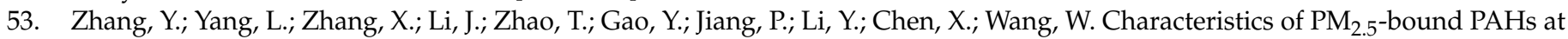
an Urban Site and a Suburban Site in Jinan in North China Plain. Aerosol Air Qual. Res. 2019, 19, 871-884. [CrossRef]

54. Mohamad, N.; Latif, M.T.; Khan, M.F. Source apportionment and health risk assessment of PM $_{10}$ in a naturally ventilated school in a tropical environment. Ecotox. Environ. Saf. 2016, 124, 351-362. [CrossRef]

55. Yabueng, N.; Wiriya, W.; Chantara, S. Influence of zero-burning policy and climate phenomena on ambient $\mathrm{PM}_{2.5}$ patterns and PAHs inhalation cancer risk during episodes of smoke haze in Northern Thailand. Atmos. Environ. 2020, 232, 117485. [CrossRef]

56. Richmond-bryant, J.; Saganich, C.; Bukiewicz, L.; Kalin, R. Associations of $\mathrm{PM}_{2.5}$ and black carbon concentrations with traffic, idling, background pollution, and meteorology during school dismissals. Sci. Total Environ. 2009, 407, 3357-3364. [CrossRef]

57. Xu, H.; Guinot, B.; Cao, J.; Li, Y.; Niu, X.; Ho, K.F.; Shen, Z.; Liu, S.; Zhang, T.; Lei, Y.; et al. Source, health risk and composition impact of outdoor very fine particles (VFPs) to school indoor environment in Xi'an, North western China. Sci. Total Environ. 2018, 612, 238-246. [CrossRef]

58. Di Gilio, A.; Farella, G.; Marzocca, A.; Giua, R.; Assennato, G.; Tutino, M.; de Gennaro, G. Indoor/Outdoor Air Quality Assessment at School near the Steel Plant in Taranto (Italy). Adv. Meteorol. 2017, 2017, 1526209. [CrossRef]

59. Oliveira, M.; Slezakova, K.; Madureira, J.; De Oliveira, E.; Delerue-matos, C.; Morais, S.; Pereira, C. Polycyclic aromatic hydrocarbons in primary school environments: Levels and potential risks. Sci. Total Environ. 2017, 575, 1156-1167. [CrossRef] [PubMed]

60. Hassanvand, M.S.; Naddafi, K.; Faridi, S.; Nabizadeh, R.; Sowlat, M.H.; Momeniha, F.; Gholampour, A.; Arhami, M.; Kashani, H.; Zare, A.; et al. Characterisation of PAHs and metals in indoor/outdoor $\mathrm{PM}_{10} / \mathrm{PM}_{2.5} / \mathrm{PM}_{1}$ in a retirement home and a school dormitory. Sci. Total Environ. 2015, 527-528, 100-110. [CrossRef] [PubMed]

61. Gao, Y.; Guo, X.; Ji, H.; Li, C.; Ding, H.; Briki, M.; Tang, L.; Zhang, Y. Potential threat of heavy metals and PAHs in PM 2.5 in different urban functional areas of Beijing. Atmos. Res. 2016, 178-179, 6-16. [CrossRef]

62. Ana, G.R.E.E.; Sridhar, M.K.C.; Emerole, G.O. Polycyclic aromatic hydrocarbon burden in ambient air in selected Niger Delta communities in Nigeria. J. Air Waste Manag. Assoc. 2012, 62, 18-25. [CrossRef]

63. Zhang, W.; Zhang, S.; Wan, C.; Yue, D.; Ye, Y.; Wang, X. Source diagnostics of polycyclic aromatic hydrocarbons in urban road runoff, dust, rain and canopy throughfall. Environ. Pollut. 2008, 153, 594-601. [CrossRef]

64. Bucheli, T.D.; Blum, F.; Desaules, A.; Gustafsson, O. Polycyclic aromatic hydrocarbons, black carbon, and molecular markers in soils of Switzerland. Chemosphere 2004, 56, 1061-1076. [CrossRef]

65. Akyuz, M.; Cabuk, H. Meteorological variations of $\mathrm{PM}_{2.5} / \mathrm{PM}_{10}$ concentrations and particle-associated polycyclic aromatic hydrocarbons in the atmospheric environment of Zonguldak, Turkey. J. Hazard. Mater. 2009, 170, 13-21. [CrossRef] [PubMed]

66. Yunker, M.B.; Macdonald, R.W.; Vingarzan, R.; Mitchell, R.H.; Goyette, D.; Sylvestre, S. PAHs in the Fraser River basin: A critical appraisal of PAH ratios as indicators of PAH source and composition. Org. Geochem. 2002, 33, 489-515. [CrossRef]

67. Fang, G.C.; Wu, Y.S.; Chen, M.H.; Ho, T.T.; Huang, S.H.; Rau, J.Y. Polycyclic aromatic hydrocarbons study in Taichung, Taiwan, during 2002-2003. Atmos. Environ. 2004, 38, 3385-3391. [CrossRef]

68. Liu, Y.; Wang, S.; Lohmann, R.; Yu, N.; Zhang, C.; Gao, Y.; Zhao, J.; Ma, L. Source apportionment of gaseous and particulate PAHs from traffic emission using tunnel measurements in Shanghai, China. Atmos. Environ. 2015, 107, 129-136. [CrossRef] 
69. Lin, Y.C.; Li, Y.C.; Shangdiar, S.; Chou, F.C.; Sheu, Y.T.; Cheng, P.C. Assessment of $\mathrm{PM}_{2.5}$ and PAH content in PM 2.5 emitted from mobile source gasoline-fueled vehicles in concomitant with the vehicle model and mileages. Chemosphere 2019, 226, 502-508. [CrossRef]

70. Zhang, Y.; Guo, C.S.; Xu, J.; Tian, Y.Z.; Shi, G.L.; Feng, Y.C. Potential source contributions and risk assessment of PAHs in sediments from Taihu Lake, China: Comparison of three receptor models. Water Res. 2012, 46, 3065-3073. [CrossRef]

71. Kwon, H.O.; Choi, S.D. Polycyclic aromatic hydrocarbons (PAHs) in soils from a multi-industrial city, South Korea. Sci. Total Environ. 2014, 470-471, 1494-1501. [CrossRef] [PubMed]

72. Yang, B.; Zhou, L.; Xue, N.; Li, F.; Li, Y.; Vogt, R.D.; Cong, X.; Yan, Y.; Liu, B. Source apportionment of polycyclic aromatic hydrocarbons in soils of Huanghuai Plain, China: Comparison of three receptor models. Sci. Total Environ. 2013, 443, 31-39. [CrossRef]

73. Thang, P.Q.; Kim, S.J.; Lee, S.J.; Ye, J.; Seo, Y.K.; Baek, S.O.; Choi, S.D. Seasonal characteristics of particulate polycyclic aromatic hydrocarbons (PAHs) in a petrochemical and oil refinery industrial area on the west coast of South Korea. Atmos. Environ. 2019, 198, 398-406. [CrossRef]

74. Freeman, D.J.; Cattell, F.C. Woodburning as a source of atmospheric polycyclic aromatic hydrocarbons. Environ. Sci. Tech. 2019, 24, 1581-1585. [CrossRef]

75. Slezakova, K.; Oliveira, M.; Madureira, J.; de Oliveira Fernandes, E.; Delerue-matos, C.; Morais, S.; do Carmo Pereira, M. Polycyclic aromatic hydrocarbons $(\mathrm{PAH})$ in Portuguese educational settings: A comparison between preschools and elementary schools. J. Toxicol. Environ. Health A 2017, 80, 630-640. [CrossRef] [PubMed]

76. Jamhari, A.A.; Sahani, M.; Latif, M.T.; Chan, K.M.; Seng, H.; Khan, M.F.; Mohd Tahir, N. Concentration and source identification of polycyclic aromatic hydrocarbons (PAHs) in $\mathrm{PM}_{10}$ of urban, industrial and semi-urban areas in Malaysia. Atmos. Environ. 2014, 86, 16-27. [CrossRef]

77. Byambaa, B.; Yang, L.; Matsuki, A.; Nagato, E.G.; Gankhuyag, K.; Chuluunpurev, B.; Banzragch, L.; Chonokhuu, S.; Tang, N.; Hayakawa, K. Sources and characteristics of polycyclic aromatic hydrocarbons in ambient total suspended particles in Ulaanbaatar City, Mongolia. Int. J. Environ. Res. Public Health 2019, 16, 442. [CrossRef] [PubMed]

78. Grmasha, R.A.; Al-sareji, O.J.; Salman, J.M.; Hashim, K.S. Polycyclic aromatic hydrocarbons (PAHs) in urban street dust within three land-uses of Babylon governorate, Iraq: Distribution, sources, and health risk assessment. J. King Saud Uni. Engin. Sci. 2020. [CrossRef]

79. Fandi, N.F.M.; Jalaludin, J.; Latif, M.T.; Hamid, H.H.A.; Awang, M.F. BTEX exposure assessment and inhalation health risks to traffic policemen in the Klang valley region, malaysia. Aerosol Air Qual. Res. 2020, 20, 1922-1937. [CrossRef]

80. Giri, S.; Singh, A.K.; Mahato, M.K. Monte Carlo simulation-based probabilistic health risk assessment of metals in groundwater via ingestion pathway in the mining areas of Singhbhum copper belt, India. Int. J. Environ. Res. Public Health 2020, 30, 447-460. [CrossRef]

81. Coronas, M.V.; Pereira, T.S.; Rocha, J.A.V.; Lemos, A.T.; Fachel, J.M.G.; Salvadori, D.M.F.; Vargas, V.M.F. Genetic biomonitoring of an urban population exposed to mutagenic airborne pollutants. Environ. Int. 2009, 35, 1023-1029. [CrossRef]

82. Aksu, İ.; Anlar, H.G.; Taner, G.; Bacanl, M.; Servet, İ.; Tutkun, E. Assessment of DNA damage in welders using comet and micronucleus assays. Mutat. Res. Genet. Toxicol. Environ. Mutagen. 2019, 843, 40-45. [CrossRef]

83. Zalata, A.; Yahia, S.; El-bakary, A.; Elsheikha, H.M. Increased DNA damage in children caused by passive smoking as assessed by comet assay and oxidative stress. Mutat. Res. 2007, 629, 140-147. [CrossRef] [PubMed]

84. Beyoglu, D.; Ozkozaci, T.; Akici, N.; Omurtag, G.Z.; Akici, A.; Ceran, O.; Sardas, S. Assessment of DNA damage in children exposed to indoor tobacco smoke. Int. J. Hyg. Environ. Health 2010, 213, 40-44. [CrossRef]

85. Gajski, G.; Geri, M.; Orescanin, V.; Garaj-vrhovac, V. Cytogenetic status of healthy children assessed with the alkaline comet assay and the cytokinesis-block micronucleus cytome assay. Mutat. Res. Genet. Toxicol. Environ. Mutagen. 2013, 750, 55-62. [CrossRef]

86. Xu, P.; Chen, Z.; Chen, Y.; Feng, L.; Wu, L.; Xu, D.; Wang, X.; Lou, X.; Lou, J. Body burdens of heavy metals associated with epigenetic damage in children living in the vicinity of a municipal waste incinerator. Chemosphere 2019, 229, 160-168. [CrossRef]

87. Hofer, T.I.M.; Karlsson, H.L.; Mo, L. DNA oxidative damage and strand breaks in young healthy individuals: A gender difference and the role of lifestyle factors. Free Radic. Res. 2006, 40, 707-714. [CrossRef] [PubMed]

88. Setayesh, T.; Nersesyan, A.; Misik, M.; Ferk, F.; Langie, S.; Andrade, V.M.; Haslberger, A.; Knasmuller, S. Impact of obesity and overweight on DNA stability: Few facts and many hypotheses. Mutat. Res. Rev. Mutat. Res. 2018, 777, 64-91. [CrossRef]

89. Alomirah, H.; Al-Zenki, S.; Al-Hooti, S.; Zaghloul, S.; Sawaya, W.; Ahmed, N.; Kannan, K. Concentrations and dietary exposure to polycyclic aromatic hydrocarbons (PAHs) from grilled and smoked foods. Food Control 2011, 22, 2028-2035. [CrossRef]

90. Schoket, B. DNA damage in humans exposed to environmental and dietary polycyclic aromatic hydrocarbons. Mutat. Res. 1999, 424, 143-153. [CrossRef]

91. Slyskova, J.; Lorenzo, Y.; Karlsen, A.; Carlsen, M.H.; Novosadova, V.; Blomhoff, R.; Vodicka, C.; Collins, A.R. Both genetic and dietary factors underlie individual differences in DNA damage levels and DNA repair capacity. DNA Repair 2014, 16, 66-73. [CrossRef]

92. Fenech, M. Chapter 4-The Role of Nutrition in DNA Replication, DNA Damage Prevention and DNA Repair. In Principles of Nutrigenetics and Nutrigenomics; Caterina, R.D., Martinez, J.A., Kohlmeier, M., Eds.; Academic Press: Cambridge, MA, USA, 2020; pp. 22-32. 
93. Naz, M.; Rehman, N.; Nazam, M.; Kamal, M.; Ganaie, M.A.; Awaad, A.S.; Alqasoumi, S.I. Comparative study of sub-chronic toxicities of mosquito repellents (coils, mats and liquids) on vital organs in Swiss albino mice. Saudi Pharm. J. 2019, $27,348-353$. [CrossRef] [PubMed]

94. Roy, D.N.; Goswami, R.; Pal, A. The Insect repellents: A silent environmental chemical toxicant to the health. Environ. Toxicol. Pharmacol. 2017, 50, 91-102. [CrossRef] [PubMed]

95. Madhubabu, G.; Yenugu, S. Effect of continuous inhalation of allethrin-based mosquito coil smoke in the male reproductive tract of rats. Inhal. Toxicol. 2012, 24, 143-152. [CrossRef] [PubMed]

96. Liu, W.; Zhang, J.; Hashim, J.H.; Jalaludin, J.; Hashim, Z.; Goldstein, B.D. Mosquito coil emissions and health implications. Environ. Health Perspect. 2003, 111, 1454-1460. [CrossRef]

97. Szeto, Y.T.; Leong, S.W.K.; Lam, K.K.; Hong, C.M.M.; Lee, D.K.M.; Chan, Y.T.F.; Benzie, I.F.F. Effects of incense smoke on human lymphocyte DNA. J. Toxicol. Environ. Health A 2009, 72, 369-373. [CrossRef]

98. Chen, S.; Wong, R.; Shiu, L.; Chiou, M.; Lee, H. Exposure to Mosquito Coil Smoke Maybe a Risk Factor for Lung Cancer in Taiwan. J. Epidemiol. 2008, 18, 19-25. [CrossRef]

99. Zhang, J.; Qi, H.; Sun, Y.P.; Xie, H.K.; Zhou, C.C. Mosquito coil exposure associated with small cell lung cancer: A report of three cases. Oncol. Lett. 2015, 9, 1667-1671. [CrossRef]

100. Gamboa, R.T.; Gamboa, A.R.; Bravo, A.H.; Ostrosky, W.P. Genotoxicity in child populations exposed to Polycyclic Aromatic Hydrocarbons (PAHs) in the air from Tabasco, Mexico. Int. J. Environ. Res. Public Health 2008, 5, 349-355. [CrossRef]

101. Ismail, I.; Jalaludin, J.; Abu Bakar, S.; Hisamuddin, N.H.; Suhaimi, N.F. Association of traffic-related air pollution (TRAP) with DNA damage and respiratory health symptoms among primary school children in Selangor. Asian J. Atmos. Environ. 2019, 13, 106-116. [CrossRef]

102. Reyna-bensusan, N.; Wilson, D.C.; Smith, S.R. Uncontrolled burning of solid waste by households in Mexico is a significant contributor to climate change in the country. Environ. Res. 2018, 163, 280-288. [CrossRef]

103. Wiriya, W.; Prapamontol, T.; Chantara, S. PM 10 -bound polycyclic aromatic hydrocarbons in Chiang Mai (Thailand): Seasonal variations, source identification, health risk assessment and their relationship to air-mass movement. Atmos. Res. 2013, 124, 109-122. [CrossRef]

104. Courter, L.A.; Pereira, C.; Baird, W.M. Diesel exhaust influences carcinogenic PAH-induced genotoxicity and gene expression in human breast epithelial cells in culture. Mutat. Res. 2007, 625, 72-82. [CrossRef]

105. Duan, H.; Leng, S.; Pan, Z.; Dai, Y.; Niu, Y.; Huang, C.; Bin, P.; Wang, Y.; Liu, Q.; Chen, W.; et al. Biomarkers measured by cytokinesis-block micronucleus cytome assay for evaluating genetic damages induced by polycyclic aromatic hydrocarbons. Mutat. Res. Gen. Toxicol. Environ. Mutag. 2009, 677, 93-99. [CrossRef] [PubMed]

106. Felipe, M.; Galv, D.O.; Regina, S.; De Medeiros, B.; Dreij, K. Genotoxicity and DNA damage signalling in response to complex mixtures of PAHs in biomass burning particulate matter from cashew. Environ. Pol. 2020, 256, 113381.

107. Muthusamy, S.; Peng, C.; Ng, J.C. Genotoxicity evaluation of multi-component mixtures of polycyclic aromatic hydrocarbons (PAHs), arsenic, cadmium, and lead using flow cytometry-based micronucleus test in HepG2 cells. Mutat. Res. Gen. Toxicol. Environ. 2018, 827, 9-18. [CrossRef] [PubMed]

108. Liu, X.; Zhang, H.; Pan, W.; Xue, Q.; Fu, J.; Liu, G.; Zheng, M.; Zhang, A. A novel computational solution to the health risk assessment of air pollution via joint toxicity prediction: A case study on selected PAH binary mixtures in particulate matters. Ecotox. Environ. Saf. 2019, 170, 427-435. [CrossRef] [PubMed] 